\title{
The Disease-Modifying Therapies of Relapsing-Remitting Multiple Sclerosis and Liver Injury: A Narrative Review
}

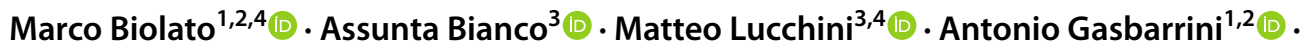 \\ Massimiliano Mirabella ${ }^{3,4}$ (D) Antonio Grieco ${ }^{1,2}$ (D)
}

Accepted: 28 June 2021 / Published online: 28 July 2021

(c) The Author(s) 2021

\begin{abstract}
In this narrative review, we analyze pre-registration and post-marketing data concerning hepatotoxicity of all diseasemodifying therapies (DMTs) available for the treatment of relapsing-remitting multiple sclerosis, including beta interferon, glatiramer acetate, fingolimod, teriflunomide, dimethyl fumarate, cladribine, natalizumab, alemtuzumab, and ocrelizumab. We review the proposed causal mechanisms described in the literature and we also address issues like use of DMTs in patients with viral hepatitis or liver cirrhosis. Most data emerged in the post-marketing phase by reports to national pharmacovigilance agencies and published case reports or case series. Serious liver adverse events are rare, but exact incidence is largely unknown, as are predictive factors. Unfortunately, none of the DMTs currently available for the treatment of multiple sclerosis is free of potential hepatic toxic effects. Cases of acute liver failure have been reported for beta-interferon, fingolimod, natalizumab, alemtuzumab, and ocrelizumab by different mechanisms (idiosyncratic reaction, autoimmune hepatitis, or viral reactivation). Patients with multiple sclerosis should be informed about possible hepatic side effects of their treatment. Most cases of liver injury are idiosyncratic and unpredictable. The specific monitoring schedule for each DMT has been reviewed and the clinician should be ready to recognize clinical symptoms suggestive for liver injury. Not all DMTs are indicated in cirrhotic patients. For some DMTs, screening for hepatitis B virus and hepatitis $\mathrm{C}$ virus is required before starting treatment and a monitoring or antiviral prophylaxis schedule has been established. Beta interferon, glatiramer acetate, natalizumab, and alemtuzumab are relatively contraindicated in autoimmune hepatitis due to the risk of disease exacerbation.
\end{abstract}

\section{Plain Language Summary}

Many disease-modifying therapies (DMTs) are approved for multiple sclerosis treatment, but liver injury is a concern. Patients can experience transaminase elevation during DMT treatment, and in rare cases, idiosyncratic and unpredictable acute liver failure. Currently, it is not possible to predict or prevent serious liver-related adverse events. Furthermore, autoimmune hepatitis and viral reactivation can also occur during DMT treatments. Since adverse events are greatly underreported, it is important to report cases of serious liver-related adverse events in the literature with adequate causality documentation to better understand the liver safety profiles of DMTs.

Marco Biolato

marco.biolato@policlinicogemelli.it

1 Department of Medical and Surgical Sciences, Fondazione Policlinico Universitario Agostino Gemelli IRCCS, Largo A. Gemelli 8, 00168 Rome, Italy

2 Institute of Internal Medicine, Catholic University of Sacred Heart, 00168 Rome, Italy

3 Multiple Sclerosis Center, Department of Department of Aging, Neurological, Orthopedic and Head and Neck Sciences, Fondazione Policlinico Universitario Agostino Gemelli IRCCS, 00168 Rome, Italy

4 Centro di ricerca per la Sclerosi Multipla (CERSM), Università Cattolica del Sacro Cuore, 00168 Rome, Italy 


\section{Key Points}

Patients with relapsing-remitting multiple sclerosis can experience transaminase elevation during treatment with disease-modifying therapies, and in rare cases, idiosyncratic and unpredictable acute liver failure.

Different mechanisms of liver injury, including idiosyncratic reaction, autoimmune hepatitis, and viral reactivation, have been reported.

Neurologists should know the monitoring schedule for each disease-modifying therapy and how to manage an alteration of liver function tests during treatment.

\section{Introduction}

In the past 20 years, the treatment scenario of relapsingremitting multiple sclerosis (MS) has radically changed, with several disease-modifying therapies (DMTs) capable of reducing the frequency of relapses, disability accrual, and accumulation of irreversible damage by interfering with a variety of immunological mechanisms [1]. According to an escalation treatment strategy, we can classify DMTs into first-line treatments (beta interferon, glatiramer acetate, teriflunomide, dimethyl fumarate) and second-line treatments (natalizumab, fingolimod, alemtuzumab, cladribine, ocrelizumab), but treatment allocation is driven by an individualized evaluation of the risk-benefit profile, including the use of an induction strategy in certain patients [2].

Drug-induced liver injury (DILI) has received considerable attention by regulators, companies, researchers, and clinicians and currently represents the most common cause for stopping drug development or restricting indications after marketing authorization [3]. For example, in 2018 the European Medicines Agency (EMA) withdrew daclizumab, a monoclonal antibody initially approved for treatment of MS, due to serious and potentially fatal immune reactions (liver injury and encephalitis) [4].

In the pre-registration phase, Hy's law is the most specific predictor of a drug's potential to cause severe hepatotoxicity. Hy's law cases combine elevation of alanine aminotransferase (ALT) or aspartate aminotransferase (AST) $>3$ times the upper limit of normal (ULN) with total bilirubin $>2 \times$ ULN, and absence of a plausible alternative cause. Patients fulfilling Hy's law experience liver failure that is fatal or requires liver transplantation in at least $10 \%$ of cases [5]. The US Food and Drug Administration (FDA) has applied Hy's law since 1997 by blocking development of drugs with more than one Hy's law case in the clinical trial database [6]. The main limitation of Hy's law is that it depends on the size of the population exposed to the drug to detect idiosyncratic DILI cases when these cases have a rare incidence. If the incidence of severe liver injury is $1 / 10,000$, at least 30,000 treated patient-years are required to have a $95 \%$ chance of detection [7]. None of the DMTs covered by this review had Hy's law cases in the pre-registration phase.

Every randomized controlled trial includes a detailed assessment of ALT and AST elevations (Table 1). Unfortunately, severity of liver injury is determined less accurately by ALT/AST elevations alone. Since 1983, the National Cancer Institute of the United States and National Institutes of Health published their Common Toxicity Criteria for Adverse Events (CTCAE), which set grades for elevations of serum transaminases. These have been updated periodically. Version 5.0 was published in 2017 and graded ALT/ AST elevations as grade 1 , mild $(<3 \times \mathrm{ULN})$; grade 2 , moderate $(>3$ to $<5 \times \mathrm{ULN})$; grade 3 , severe $(>5$ to $<20 \times$ ULN) and grade 4, life-threatening ( $>20 \times$ ULN) [8]. Grade 1 elevations are much less specific for DILI and can also be observed in placebo-treated patients or healthy individuals, often confounded by the effects of physical exercise or diets [9]. Moreover, grade 1 ALT/AST elevations were transient in most patients and often fell into the normal range even with continued treatment or with transient dose reduction or interruption. Directly translating the frequency of transaminase elevations during therapy into hepatotoxicity can be misleading.

For these reasons, the post-marketing phase is pivotal to monitor drug safety and gain insight into its real risk-benefit profile as it reflects actual clinical practice where comorbidities and poly-pharmacotherapy exist. There are two main sources for intercepting hepatotoxicity signals from drugs released on the market: reports to national pharmacovigilance agencies and published case reports or case series of toxic liver reactions. Both systems suffer from an underreporting problem, but case reports are more informative in determining causality. In general, the occurrence of a fatal case of liver injury defines the drug as a serious potential hepatotoxin, whereas a positive rechallenge represents the most convincing evidence for causality in DILI [10]. In the Livertox ${ }^{\circledR}$ database, drugs are classified into categories based on the number of published reports of convincingly documented, clinically apparent, idiosyncratic liver injury. Spontaneous reports to regulatory agencies or provided by the drug manufacturers are not included (Table 2).

As widely reported in recent literature $[11,12]$, extensive infectious disease screening is recommended at MS diagnosis and before starting a new DMT. The aim of infectious disease screening is to plan vaccinations or laboratory monitoring and start prophylaxis or treatment of latent or occult infections. This screening generally includes hepatitis 
Table 1 Phase III liver safety results of disease-modifying therapies (DMTs)

\begin{tabular}{|c|c|c|c|c|c|}
\hline Agent & Trial, year of publication & $\begin{array}{l}\text { No. patients } \\
\text { exposed }\end{array}$ & $\begin{array}{l}\text { Years of } \\
\text { exposure }\end{array}$ & ALT/AST elevation (Grade 1$)^{\mathrm{a}}$ & $\begin{array}{l}\text { ALT/AST } \\
\text { elevation } \\
(\text { Grade } 3)^{\mathrm{a}}\end{array}$ \\
\hline \multicolumn{6}{|c|}{ Injective treatments } \\
\hline \multirow[t]{21}{*}{ Beta interferon } & IFNB MS, 1993 [16] & 226 & 2 & $9 \%^{b}$ & $1 \%$ \\
\hline & MSCRG, 1996 [17] & 158 & 2 & $<10 \%^{\mathrm{b}}$ & n.r. \\
\hline & PRISMS, 1998 [18] & 373 & 2 & $4 \%^{\mathrm{b}}$ & $<1 \%$ \\
\hline & SPECTRIMS, 2001 [22] & 413 & 3 & $12 \% \mathrm{~b}$ & n.r. \\
\hline & EVIDENCE, 2002 [19] & 676 & 1.5 & $14 \%$ & $2 \%$ \\
\hline & Nordic SPMS, 2004 [23] & 186 & 3 & $48 \%$ & n.r. \\
\hline & SENTINEL, 2006 [148] & 582 & 2 & $<5 \%$ & $<1 \%$ \\
\hline & BENEFIT, 2006 [24] & 292 & 2 & n.r. & $17.8 \%$ \\
\hline & OPERA I and II, 2017 [186] & 826 & 2 & $<10 \%$ & $<1 \%$ \\
\hline & REGARD, 2008 [54] & 381 & 3.5 & $10 \%$ & $<1 \%$ \\
\hline & CAMMS223, 2008 [157] & 107 & 3 & $15 \%$ & $1 \%$ \\
\hline & RNF, 2009 [20] & 260 & 2 & $14 \%$ & $4 \%$ \\
\hline & BEYOND, 2009 [56] & 1775 & 3.5 & $13 \%$ & n.r. \\
\hline & TRANSFORMS, 2010 [80] & 431 & 1 & $2 \%^{\mathrm{b}}(2 \%$ Grade 2$)$ & $<1 \%$ \\
\hline & REFLEX, 2012 [21] & 344 & 2 & $10 \%$ & n.r. \\
\hline & CARE MS I, 2012 [161] & 187 & 2 & $17 \%$ & $1 \%$ \\
\hline & CARE MS II, 2012 [162] & 187 & 2 & $17 \%$ & $1 \%$ \\
\hline & TENERE, 2014 [112] & 101 & 2 & $57 \%$ (12\% Grade 2$)$ & $4 \%$ \\
\hline & ADVANCE, 2015 [25] & 1332 & 2 & $35 \%$ (3\% Grade 2 ) & $1 \%$ \\
\hline & ONWARD, 2016 [141] & 57 & 2 & $6 \%$ & $2 \%$ \\
\hline & PARADIGMS, 2018 [83] & 107 & 2 & $5 \%$ & $<1 \%$ \\
\hline \multirow[t]{5}{*}{ Glatiramer acetate } & PROMISE, 2007 [203] & 627 & 3 & $<5 \%$ b & n.r. \\
\hline & REGARD, 2008 [54] & 375 & 2 & $4 \%^{\mathrm{b}}$ & $<1 \%$ \\
\hline & BEYOND, 2009 [56] & 445 & 3.5 & $4 \% \%^{b}$ & n.r. \\
\hline & PRECISE, 2009 [55] & 243 & 3 & $<2 \%$ b & $<1 \%$ \\
\hline & CONFIRM, 2012 [57] & 351 & 2 & $37 \%$ (7\% Grade 2) & $3 \%$ \\
\hline \multicolumn{6}{|l|}{ Oral treatments } \\
\hline \multirow[t]{5}{*}{ Fingolimod } & FREEDOMS, 2010 [79] & 854 & 2 & $17 \%^{\mathrm{b}}(10 \%$ Grade 2$)$ & $2 \%$ \\
\hline & TRANSFORMS, 2010 [80] & 849 & 1 & $7 \%^{\mathrm{b}}(8 \%$ Grade 2$)$ & n.r. \\
\hline & FREEDOMS II, 2014 [81] & 728 & 2 & $9 \%$ (8\% Grade 2) & $2 \%$ \\
\hline & INFORMS, 2016 [82] & 483 & 4 & $12 \%$ & n.r. \\
\hline & PARADIGMS, 2018 [83] & 107 & 2 & $4 \%$ & $1 \%$ \\
\hline \multirow[t]{4}{*}{ Teriflunomide } & TEMSO, 2011 [109] & 726 & 2 & $56 \%$ (6\% Grade 2) & $1 \%$ \\
\hline & TOWER, 2014 [110] & 780 & 2 & $12 \%$ (8\% Grade 2$)$ & $3 \%$ \\
\hline & TOPIC, 2014 [111] & 423 & 2 & $18 \%$ (12\% Grade 2$)$ & $5 \%$ \\
\hline & TENERE, 2014 [112] & 220 & 2 & $39 \%$ (6\% Grade 2 ) & $2 \%$ \\
\hline \multirow[t]{3}{*}{ Dimethyl fumarate } & DEFINE, 2012 [123] & 826 & 2 & n.r. $(6 \%$ Grade 2$)$ & n.r. \\
\hline & CONFIRM, 2012 [57] & 703 & 2 & $51 \%$ (6\% Grade 2$)$ & $2 \%$ \\
\hline & APEX part 1, 2019 [124] & 111 & 0.5 & $32 \%$ (5\% Grade 2 ) & $<1 \%$ \\
\hline \multirow[t]{3}{*}{ Cladribine } & CLARITY, 2010 [138] & 884 & 2 & $<10 \%$ & $<2 \%$ \\
\hline & ORACLE MS, 2014 [140] & 616 & 2 & $<5 \%$ & $<1 \%$ \\
\hline & ONWARD, 2018 (plus INF $\beta 1 a)$ [141] & 172 & 2 & $2 \%$ & $<1 \%$ \\
\hline \multicolumn{6}{|c|}{ Infusional treatments } \\
\hline \multirow[t]{4}{*}{ Natalizumab } & AFFIRM, 2006 [147] & 627 & 2 & $5 \%$ & $<1 \%$ \\
\hline & SENTINEL, 2006 (plus INF $\beta 1$ a) [148] & 516 & 2 & $<5 \%$ & $<1 \%$ \\
\hline & ASCEND, 2018 part 1 [149] & 439 & 2 & $<10 \%$ & None \\
\hline & ASCEND, 2018 part 2 [149] & 566 & 2 & $<10 \%$ & None \\
\hline
\end{tabular}


Table 1 (continued)

\begin{tabular}{llllll}
\hline Agent & Trial, year of publication & $\begin{array}{l}\text { No. patients } \\
\text { exposed }\end{array}$ & $\begin{array}{l}\text { Years of } \\
\text { exposure }\end{array}$ & ALT/AST elevation (Grade 1) & $\begin{array}{l}\text { ALT/AST } \\
\text { elevation } \\
(\text { Grade 3) }\end{array}$ \\
\hline Alemtuzumab & CAMMS223, 2008 [157] & 216 & 3 & $2 \%$ & $<1 \%$ \\
& CARE MS I, 2012 [161] & 376 & 2 & $4 \%$ & 0 \\
& CARE MS II, 2012 [162] & 596 & 2 & $4 \%$ & $<1 \%$ \\
Ocrelizumab & OPERA I and II, 2017 [186] & 825 & 2 & $1 \%$ & None \\
& ORATORIO, 2017 [187] & 482 & 2.5 & $2 \%$ & None \\
\hline
\end{tabular}

$A L T$ alanine aminotransferase, $A S T$ aspartate aminotransferase, $n . r$. not reported

${ }^{a}$ According to Common Terminology Criteria for Adverse Events, version 5.0

bWhen values of laboratory abnormalities were not reported in the paper, we report the data of adverse events by investigators' judgment, which means that an abnormal liver function test is considered an adverse event only when elevated liver function test levels were reported as adverse events by the investigators

Table 2 Disease-modifying therapies (DMTs) according to LiverTox categorization

\begin{tabular}{lll}
\hline Agent & Category & Last update \\
\hline $\begin{array}{l}\text { Injective treatments } \\
\text { Beta interferon }\end{array}$ & A & May 4, 2018 \\
$\begin{array}{l}\text { Glatiramer acetate } \\
\text { Oral treatments }\end{array}$ & B & March 14, 2018 \\
$\begin{array}{l}\text { Fingolimod } \\
\text { Teriflunomide }\end{array}$ & E* & February 6, 2018 \\
$\begin{array}{l}\text { Dimethyl fumarate } \\
\text { Cladribine }\end{array}$ & D & January 15, 2017 \\
$\begin{array}{l}\text { Infusional treatments } \\
\text { Natalizumab }\end{array}$ & E & July 1, 2017 \\
Alemtuzumab & B & October 12, 2017 \\
Ocrelizumab & C & \\
\hline
\end{tabular}

Drugs described on the website LiverTox (http://livertox.nih.gov) were classified into five categories based on the number of published cases:

Category A, $\geq 50$ cases

Category B, $12-49$ cases

Category C, 4-11 cases

Category D, 1-3 cases

Category E, none (*These agents have been suspected of having hepatotoxicity or were implicated in published cases that did not meet the criteria of possibly causality using the RUCAM method)

This listing is based on the published literature and not on spontaneous reports to regulatory agencies or the drug manufacturers

$B$ virus (HBV) and hepatitis $\mathrm{C}$ virus (HCV). Screening tests should include HBsAg, HBcAb, HBsAb, and HCVAb. All patients positive for any of these markers should be referred to a specialist, with the exception of HBV-vaccinated patients with isolated HBsAb reactivity. MS patients with acute or chronic HBV or HCV infections should receive antiviral therapy and the timing for starting DMT therapy should be discussed with the hepatologist or the infectious disease specialist. MS patients with occult HBV infection should undergo periodic monitoring or prophylaxis, depending on the immunomodulatory treatment chosen. Patients negative for all $\mathrm{HBV}$ markers are candidates to start the vaccination course before receiving DMT therapy [13].

In this narrative review, we analyze pre-registration and post-marketing data of hepatotoxicity of DMTs for the treatment of relapsing-remitting MS (Table 3). We also address issues like use of DMTs in patients with HBV and HCVrelated viral hepatitis or liver cirrhosis (Tables 4, 5). Highdose methylprednisolone is clearly hepatotoxic by direct toxicity (as opposed to idiosyncratic injury), but methylprednisolone-induced liver injury in MS is thoroughly discussed elsewhere [14]. Drugs approved for secondary progressive MS (e.g., mitoxantrone and siponimod) or symptomatic treatments (e.g., fampridine) are outside the scope of this review. Despite all efforts to carry out an exhaustive literature search, it is still possible that some relevant papers may have been omitted and this represents a potential limitation of this narrative review.

\section{Methods}

A.B. and M.L. performed a literature search on Medline with the terms 'multiple sclerosis' [MeSH] AND 'randomized controlled trial' [Publication Type], OR 'chemical and drug induced liver injury' [MeSH], OR 'liver diseases' [MeSH], OR 'retrospective studies' [MeSH] OR 'multicenter study' [Publication Type] OR 'multiple sclerosis/drug therapy' [MeSH] OR 'immunosuppressive agents/adverse effects' [MeSH] for each DMT. We retrieved articles published between January 1993 and December 2020. References of the identified articles were reviewed to retrieve additional relevant articles. Only papers published in English were 
Table 3 Disease-modifying therapies (DMTs) and risk of liver injury

\begin{tabular}{|c|c|c|c|c|c|}
\hline \multirow[t]{2}{*}{ Agent } & \multicolumn{2}{|c|}{ Phase III safety results } & \multirow[t]{2}{*}{ Year of FDA approval } & \multirow[t]{2}{*}{ Post-marketing data } & \multirow[t]{2}{*}{ Cases of acute liver failure } \\
\hline & $\begin{array}{l}\text { Grade } 1 \text { ALT/ } \\
\text { AST eleva- } \\
\text { tion }\end{array}$ & $\begin{array}{l}\text { Grade } 3 \text { ALT/ } \\
\text { AST eleva- } \\
\text { tion* }\end{array}$ & & & \\
\hline \multicolumn{6}{|c|}{ Injective treatments } \\
\hline Beta interferon & $67 \%$ & $1-2 \%$ & 1993-2014 & $\begin{array}{l}\text { Drug discontinuation }<1 \% \\
\text { Some cases of DILI and autoimmune } \\
\text { hepatitis }\end{array}$ & 11 (autoimmune or DILI) \\
\hline Glatiramer acetate & $12 \%$ & $2 \%$ & 1996 & $\begin{array}{l}\text { Drug discontinuation }<1 \% \\
\text { Some cases of autoimmune hepatitis }\end{array}$ & None \\
\hline \multicolumn{6}{|l|}{ Oral treatments } \\
\hline Fingolimod & $11 \%$ & $2 \%$ & 2010 & Drug discontinuation $<1 \%$ & 3 (DILI) \\
\hline Teriflunomide & $31 \%$ & $2 \%$ & 2012 & Drug discontinuation $3-4 \%$ & $\begin{array}{l}\text { None (but several cases } \\
\text { reported for lefluno- } \\
\text { mide) }\end{array}$ \\
\hline Dimethyl fumarate & $48 \%$ & $2 \%$ & 2013 & Drug discontinuation $<1 \%$ & None \\
\hline Cladribine & $<5 \%$ & $<2 \%$ & 2019 & No data & None \\
\hline \multicolumn{6}{|c|}{ Infusional treatments } \\
\hline Natalizumab & $5 \%$ & $<1 \%$ & 2004 & $\begin{array}{l}\text { Some cases of severe hepatitis (both } \\
\text { DILI and autoimmune) }\end{array}$ & 1 (HBV) \\
\hline Alemtuzumab & $4 \%$ & $<1 \%$ & 2014 & $\begin{array}{l}\text { Autoimmune hepatitis }(10.7 / 10,000 \\
\text { patients) } \\
1 \text { case of DILI with positive rechal- } \\
\text { lenge }\end{array}$ & 3 (Autoimmune) \\
\hline Ocrelizumab & $1-2 \%$ & None & 2017 & Rare cases of HBV reactivation & 1 (Enterovirus) \\
\hline
\end{tabular}

$A L T$ alanine aminotransferase, $A S T$ aspartate aminotransferase, $D I L I$ drug-induced liver injury, $F D A$ US Food and Drug Administration, $H B V$ hepatitis B virus

*according to Common Terminology Criteria for Adverse Events, version 5.0

included in the review. The last search date was February 28, 2021.

Pre-registration data were extrapolated from randomized, controlled, phase III clinical trials. Supplementary appendices of each trial were also reviewed. In particular, for each trial we collected the acronym, the year of publication, the number of patients exposed to the study drug, the duration of exposure to the study drug, and the incidence of transaminases elevation of grade 1 and grade 3 according to CTCEA version 5.0. For studies that referred to different classifications of liver injury, these were converted to their equivalent CTCAE grade by the authors.

Post-marketing data were retrieved from all published reports available, including case reports, case series, and letters to the editor. The Livertox ${ }^{\circledR}$ database was accessed at http://livertox.nih.gov for each drug. Causality assessment was performed according to the Roussel UCLAF Causality Assessment Method (RUCAM) [15]; when RUCAM score was not reported in the paper, it was calculated by the authors on the basis of available data whenever possible.

During the literature search we selected 51 full-text papers for beta-interferon, 44 for glatiramer acetate, 37 for fingolimod, 22 for teriflunomide, 24 for dimethyl fumarate,
13 for cladribine, 16 for natalizumab, 32 for alemtuzumab, and 19 for ocrelizumab.

\section{Disease-Modifying Therapies}

\subsection{Beta Interferon}

Beta interferon is a cytokine with intracellular antiviral, antiproliferative, and immunomodulatory properties that has been approved for treatment of MS since 1993. Beta interferon is structurally distinct from alpha interferon, but they share the same cell surface receptors, although they activate separate signaling pathways. There are two types of beta interferon, IFN $\beta 1 \mathrm{a}$ and IFN $\beta 1 \mathrm{~b}$. All formulations are injections, either subcutaneous or intramuscular, and have different dosages and frequency of administration. Currently, five forms of beta interferon are available:

Betaseron/Betaferon ${ }^{\odot}$ —interferon $\beta 1 \mathrm{~b}$, subcutaneous injection $(250 \mu \mathrm{g})$ every other day. Approved 1993.

Extavia $^{\odot}$-interferon $\beta 1 \mathrm{~b}$, subcutaneous injection $(250 \mu \mathrm{g})$ every other day. Approved 1993. 
Table 4 Disease-modifying therapies (DMTs) and viral hepatitis

\begin{tabular}{|c|c|c|c|c|c|c|}
\hline \multirow[t]{2}{*}{ Agent } & \multicolumn{2}{|l|}{ Screening } & \multirow[t]{2}{*}{ Monitoring } & \multirow{2}{*}{$\begin{array}{l}\text { Cases of } \mathrm{HBV} / \mathrm{HCV} \text { reac- } \\
\text { tivation }\end{array}$} & \multirow[t]{2}{*}{ Data on $\mathrm{HBV} / \mathrm{HCV}$ patients } & \multirow[t]{2}{*}{ Other viral hepatitis } \\
\hline & $\mathrm{HBV}$ & $\mathrm{HCV}$ & & & & \\
\hline \multicolumn{7}{|l|}{ Injective treatments } \\
\hline Beta interferon & No & No & No & None & $\begin{array}{l}\text { Clearance of HCV in } 1 \\
\text { patient }\end{array}$ & n.a. \\
\hline Glatiramer acetate & No & No & No & None & n.a. & n.a. \\
\hline \multicolumn{7}{|l|}{ Oral treatments } \\
\hline Fingolimod & Yes & Yes & No & 1 case of $\mathrm{HCV}$ reactivation & n.a. & Some cases of HEV hepatitis \\
\hline Teriflunomide & Yes & Yes & No & None & n.a. & 1 case of CMV hepatitis \\
\hline Dimethyl fumarate & Yes & Yes & No & None & n.a. & 1 case of HEV hepatitis \\
\hline Cladribine & Yes & Yes & $\mathrm{No}^{\mathrm{a}}$ & 1 case of new HBV infection & n.a. & n.a. \\
\hline \multicolumn{7}{|c|}{ Infusional treatments } \\
\hline Natalizumab & Yes & Yes & No & 1 case of HBV ALF & n.a. & n.a. \\
\hline Alemtuzumab & $\begin{array}{l}\text { Yes (both } \\
\text { HbsAg } \\
\text { and } \\
\mathrm{HBcAb} \text { ) }\end{array}$ & Yes & Yes $^{b}$ & $\begin{array}{l}\text { None (reported only in } \\
\text { hematological setting) }\end{array}$ & n.a. & $\begin{array}{l}\text { Cases of HEV, CMV and } \\
\text { adenovirus hepatitis }\end{array}$ \\
\hline Ocrelizumab & $\begin{array}{l}\text { Yes (both } \\
\text { HbsAg } \\
\text { and } \\
\text { HBcAb) }\end{array}$ & Yes & $\mathrm{Yes}^{\mathrm{c}}$ & $\begin{array}{l}2 \text { cases of HBV reactiva- } \\
\text { tion in HBsAg-negative/ } \\
\text { HBcAb-positive patients }\end{array}$ & $\begin{array}{l}\text { 1/300 HBV reactivation } \\
\text { risk in HBsAg-negative/ } \\
\text { HBcAb-positive patients }\end{array}$ & $\begin{array}{l}1 \text { case of ALF associated with } \\
\text { enterovirus }\end{array}$ \\
\hline
\end{tabular}

$A L F$ acute liver failure, $C M V$ cytomegalovirus, $H B V$ hepatitis B virus, $H C V$ hepatitis $\mathrm{C}$ virus, $H E V$ hepatitis $\mathrm{E}$ virus, n.a. not available

${ }^{a}$ Contraindicated in $\mathrm{HBV}$ or $\mathrm{HCV}$ active hepatitis

${ }^{\mathrm{b}}$ Before every cycle. Prophylaxis in patients with positive HBV markers

${ }^{\mathrm{c}}$ Every 3-6 months. Prophylaxis in patients with positive HBV markers

Table 5 Liver function tests screening and monitoring schedule for disease-modifying treatments (DMTs)

\begin{tabular}{|c|c|c|c|}
\hline Agent & $\begin{array}{l}\text { Liver function } \\
\text { tests screening }\end{array}$ & ALT monitoring & Data in cirrhotic patients \\
\hline \multicolumn{4}{|c|}{ Injective treatments } \\
\hline Beta interferon & Yes & After $1,3,6$ months and periodically thereafter & Not available \\
\hline Glatiramer acetate & $\begin{array}{l}\text { No (but sug- } \\
\text { gested) }\end{array}$ & No & Not available \\
\hline \multicolumn{4}{|l|}{ Oral treatments } \\
\hline Fingolimod & Yes & After $1,3,6,9,12$ months and bimonthly thereafter & Contraindicated in Child $\mathrm{C}$ patients \\
\hline Teriflunomide & Yes & Every 2 weeks for 6 months, then bimonthly & $\begin{array}{l}\text { Contraindicated in Child C patients } \\
\text { Caution in fatty liver disease }\end{array}$ \\
\hline Dimethyl fumarate & Yes & Yes (suggested every 6 months) & Not available \\
\hline Cladribine & Yes & No & Contraindicated in Child B and C patients \\
\hline \multicolumn{4}{|c|}{ Infusional treatments } \\
\hline Natalizumab & Yes & Monthly for first 3 months, quarterly thereafter & Not available \\
\hline Alemtuzumab & Yes & Monthly up to 48 months from last infusion & Not available \\
\hline Ocrelizumab & Yes & No (but suggested semiannually) & Use only in Child A patients \\
\hline
\end{tabular}

$A L T$ alanine aminotransferase

Avonex ${ }^{\odot}$ —interferon $\beta 1 \mathrm{a}$, intramuscular injection $(30 \mu \mathrm{g})$ once weekly. Approved 1996.

Rebif $^{\oplus}$-interferon $\beta 1 \mathrm{a}$, subcutaneous injection $(8.8 \mu \mathrm{g}$, $22 \mu \mathrm{g}, 44 \mu \mathrm{g}$ ) thrice weekly. Approved 2003.
Plegridy ${ }^{\odot}$ - peginterferon $\beta 1 \mathrm{a}$, subcutaneous injection (63 $\mu \mathrm{g}, 94 \mu \mathrm{g}, 125 \mu \mathrm{g})$ every 14 days. Approved 2014.

All five forms of beta interferon have been shown to cause elevations in ALT levels (Table 1) [16-25]. The magnitude 
of the effect initially reported in pre-registration clinical trials was significantly lower than that reported in a dedicated re-analysis of clinical trials data, which collected a prevalence of up to $67 \%$ of patients (grade 1) and these elevations were graded as severe in 1-2\% of patients [26]. According to this paper, the incidence of symptomatic hepatotoxicity with interferon beta is $1 / 2300$ treated patients or $1 / 4000$ patientyears of use. Furthermore, a retrospective observational study confirmed a prevalence of ALT/AST elevations of 37\% (grade 1), of 5\% (grade 2), and of $1 \%$ (grade 3 ) in patients treated with beta interferon [27]. Transaminase elevations were more common in male sex [28], were dose related [28], and $>75 \%$ occurred during the first 6 months of treatment [28], although liver toxicity can occur even after years of exposure [29]. Most patients who achieved grade 1 and 2 ALT/AST elevations continued treatment with beta interferon despite this alteration and transaminases returned to normal values at subsequent controls [30]. In post-marketing experience, $<1 \%$ of patients discontinued beta interferon treatment because of hepatic adverse effects [30].

Beta interferon treatment requires screening of transaminase before starting the drug and periodic monitoring (after 1,3 , and 6 months, and periodically thereafter), with closer monitoring in case of elevation of transaminases $>3 \times$ ULN (Table 5). If ALT/AST elevation is $>5 \times \mathrm{ULN}$, the beta interferon dosage should be reduced from 50 to $25 \%$ (or administration delayed) and gradually increased when values return to normal, with careful laboratory monitoring. Therapy should be interrupted in case of persistent ALT/AST elevations or in case of onset of jaundice or other symptoms. Rechallenge should be avoided in cases with ALT/AST $>10$ or bilirubin $>5 \times$ ULN [31-33].

In the post-marketing phase, many cases of hepatotoxicity associated with beta interferon treatment have been reported, including cases of acute liver failure with fatal outcome, or requiring liver transplantation (Table 3 ). In some cases, the causality assessment was based on a positive rechallenge $[34,35]$. The latency to onset is extremely variable and acute injury can arise after years of treatment [36, 37]. The DrugInduced Liver Injury Network (DILIN) registry collected eight cases of beta interferon-induced liver injury, including a fatal case, that occurred in women and mostly had a hepatocellular pattern of liver damage; available liver histology demonstrated zone 3 necrosis and moderate chronic inflammatory infiltrates with lymphocytes, eosinophils, and plasma cells suggestive of an immune-mediated basis [38].

Several cases of beta interferon-induced autoimmune hepatitis have been reported. These cases were associated with detectable autoantibodies (anti-nuclear, anti-smooth muscle, anti-liver-kidney-microsomal antibodies) and hypergammaglobulinemia at presentation, had typical histological pattern at liver biopsy, and mostly responded to chronic immunosuppressive treatment (prednisone, azathioprine or mycophenolate mofetil) [39-42]. A case of primary biliary cirrhosis in a patient treated with beta interferon has been also reported [43]. Other autoimmune diseases have been associated with beta interferon treatment and include thyroiditis, myasthenia gravis, lupus erythematosus, rheumatoid arthritis, and Raynaud's phenomenon [33].

In literature, 11 case reports of acute liver failure associated with beta interferon have been published, seven of them with a final diagnosis of probable or definite autoimmune hepatitis and four with a diagnosis of DILI (but in three out of four cases, detectable autoantibodies were present). Two of them had a fatal outcome and seven underwent liver transplantation, while two recovered conservatively [41, 44-51].

Data on cirrhotic patients are not available and no cases of $\mathrm{HBV}$ or $\mathrm{HCV}$ reactivation under beta interferon have been reported (Tables 4, 5). There was a report of virological response after beta interferon treatment in a patient with both chronic HCV hepatitis and MS, but in the era of direct antiviral agents, this is anecdotal [52].

\subsection{Glatiramer Acetate}

Glatiramer acetate is a synthetic amino acid polymer antigenically similar to myelin basic protein and was approved for use in MS in 1996. Although different potential mechanisms have been considered, glatiramer acetate treatment induces a preferential Th2 deviation of $\mathrm{T}$ cells and promotes restoration of frequency and function of $\mathrm{T}$ regulatory cells in MS. Glatiramer acetate also exerts immunomodulatory effects on antigen presenting cells, such as monocytes [53]. The glatiramer acetate-recommended dosing regimen is $20 \mathrm{mg} / \mathrm{mL}$ day administered subcutaneously; in 2014 a new formulation of $40 \mathrm{mg} / \mathrm{mL}$ three times a week was introduced.

According to the phase III trials summarized in Table 1, transaminases elevation (any grade) was reported in about $12 \%$ of patients and graded as moderate in $7 \%$ of patients and as severe in $2 \%$ of patients [54-57]. Safety data, including extension studies, are available for up to 15 years of treatment $[58,59]$. Real-world observational studies from Germany [60], Switzerland [61], and France [62, 63] confirmed a $<1 \%$ drug discontinuation rate due to hepatic adverse events.

No cases of liver toxicity according to Hy's Law were reported in the pre-registration trials of glatiramer acetate, so liver function test monitoring during glatiramer treatment is not required in the drug label (Table 5). In the post-marketing phase, $>50$ cases of liver injury associated with glatiramer acetate treatment were reported to the FDA Adverse Event Reporting System (FAERS) database [64]. Fourteen cases of glatiramer-associated hepatitis have been published in the literature, 13 of which were histologically documented [65-68]. The onset has been within 1-8 months after starting therapy, with the typical presentation being a hepatocellular 
pattern of liver injury, and all patients recovered completely within 1-5 months after drug withdrawal. Some cases have occurred in patients with prior transaminases elevation during beta interferon therapy or were temporally associated with methylprednisolone bolus therapy. Three of these cases were typical autoimmune hepatitis and required long-term immunosuppressive treatment (Table 3) [69-71]. Other autoimmune diseases have been associated with glatiramer acetate treatment and include myasthenia gravis and autoimmune thyroiditis. The exact mechanism of glatiramer acetate-induced autoimmune hepatitis is unknown. The hypothesis is that glatiramer acetate may induce $\mathrm{Th} 2$ cells, leading to the release of cytokines like interleukin- 4,6 , and 10 , and autoantibody production in predisposed patients. In five cases of glatiramer acetate-induced liver injury, a transient elevation of autoantibodies (anti-nucleus, anti-smooth muscle, or both) was reported, suggesting an immune-mediated basis for the liver injury [72-75]. Makhani and colleagues reported a well-documented case of glatiramer acetateinduced liver injury possibly related to mitochondrial damage, showing microvesicular steatosis, hepatocyte necrosis, and structural mitochondrial changes at liver biopsy [76]. No cases of acute liver failure in patients treated with glatiramer acetate have been reported, or any cases of HBV or HCV reactivation (Table 4). Data on cirrhotic patients are not available (Table 5).

\subsection{Fingolimod}

Fingolimod is a structural analog of sphingosine and acts as a sphingosine-1-phosphate receptor antagonist. By blocking this pathway, naive and central memory lymphocytes (but not effector memory $\mathrm{T}$ cells) become insensitive to signals necessary for egress from secondary lymphoid organs. Fingolimod was approved for treatment of MS in 2010 and the recommended dose is $0.5 \mathrm{mg}$ orally once daily [77]. Peripheral $\mathrm{B}$ and $\mathrm{T}$ cell counts are reduced by approximately $75 \%$ from baseline after the first 1-2 weeks, an effect that persists for 4-6 weeks after withdrawal $[77,78]$.

According to the phase III trials summarized in Table 1, abnormal liver function tests (any grade) were reported in $11 \%$ of patients (pooling patients treated with fingolimod $0.5 \mathrm{mg}$ and $1.25 \mathrm{mg}$ daily) and were graded as severe in $2 \%$ of patients [79-83]. Liver function test levels returned to normal about 2 months after stopping treatment and can become elevated again in case of rechallenge. Safety data, including extension studies, are available for up to 14 years of treatment [84-86]. The hepatotoxicity signal emerging from phase III trials has had implications for the drug label. Since approval, fingolimod treatment required screening for transaminases and bilirubin before starting the drug, periodic monitoring (after 1, 3, 6, 9, 12 months, and bimonthly thereafter) and treatment interruption in case of persistent elevation of transaminases $>5 \times$ ULN .

The mechanism by which fingolimod might cause liver injury is not known. It is extensively metabolized by the liver via the cytochrome $\mathrm{P} 450$ system, predominantly CYP4F2 [87]. In patients with decompensated cirrhosis (Child $\mathrm{C}$ ), the area under the curve (AUC) of fingolimod increased by $103 \%$, the maximum concentration $\left(C_{\max }\right)$ of fingolimod phosphate decreased by $22 \%$, and the apparent curve of elimination with half-life time increased by approximately $50 \%$ [88]. For these reasons, the use of fingolimod is contraindicated in patients with severe hepatic impairment. Caution is recommended when starting fingolimod treatment in cirrhotic patients with mild or moderate hepatic decompensation (Child A and B), although no dose adjustment is required (Table 5).

Real-world observational studies showed a heterogeneous pattern of liver function test elevation, ranging from $2 \%$ in Germany [89] to 4\% in Spain [90, 91], 5\% in Italy [92], 7-25\% in the Middle East [93-95], 9\% in Argentina [96], and 13\% in Portugal [97]. Male and older patients were most frequently affected by transaminases elevation, maybe because of sex-dependent expression of cytochrome P450 [98]. Reducing the frequency of fingolimod administration to reverse moderately abnormal liver function tests is controversial [99]. According to the PARADIGM trial, liver adverse events seem lower in the pediatric population than in the adult population. One case of fingolimod-induced chronic liver injury has also been reported [100].

During subsequent post-marketing monitoring, three cases of acute liver failure requiring liver transplantation in patients treated with fingolimod were observed (Table 3 ). For this reason, in November 2020 the label of the drug was updated (Table 5), introducing further thresholds for treatment interruption (transaminases elevation $>3 \times \mathrm{ULN}$ and any bilirubin elevation, or symptomatic patient) [101, 102]. Fingolimod treatment should not be resumed unless a plausible alternative diagnosis for signs and symptoms of liver injury can be established.

Fingolimod has also been shown to attenuate the antiviral immune response in MS patients, so in patients with active viral hepatitis (HBV or HCV), fingolimod cannot be initiated until resolution of the active phase (Table 4). The risk of $\mathrm{HBV}$ reactivation in patients treated with fingolimod has not been well established but is likely low. In the TRANSFORMS trial, screening for viral hepatitis was not routinely performed but no cases of severe HBV infection were identified. In literature, a case of HCV reactivation in a patient with a 4-year sustained virological response after pegylated interferon/ribavirin antiviral therapy has been described, suggesting loss of immune control induced by fingolimod treatment [103]. Furthermore, some cases of acute hepatitis from hepatitis E virus (HEV) during fingolimod treatment 
have been reported [104-106]. These cases are generally confused with DILI if anamnestic risk factor (consumption of raw or undercooked pork meat) is missed. Fingolimod was generally discontinued in these cases and resumed after normalization of liver enzymes and complete HEV viremia clearance.

\subsection{Teriflunomide}

Teriflunomide is the active metabolite of leflunomide, an immunomodulatory agent approved for the treatment of rheumatoid arthritis. Teriflunomide reversibly inhibits dihydro-orotate dehydrogenase, which is a key step in new pyrimidine synthesis for DNA replication. The activation and proliferation of lymphocytes are dependent upon pyrimidine synthesis and therefore are deeply sensitive to its inhibition. Teriflunomide was approved for use in MS in 2012 and the recommended dose is $14 \mathrm{mg}$ orally once daily. During teriflunomide treatment lymphocyte and neutrophil counts are reduced by approximately $15 \%$ from baseline $[103,107$, 108].

According to the phase III trials summarized in Table 1, serum aminotransferase elevations occurred in up to $50 \%$ of patients and were graded as moderate in $8 \%$ of patients, leading to drug discontinuation in 2-3\% of patients [109-112]. Because of data from pre-registration trials and the known hepatotoxic potential of leflunomide, the Warnings and Precautions section of product labelling recommends ALT screening and monitoring every 2 weeks for 6 months, then bimonthly during treatment (Table 5). In case of ALT elevation $>2 \times$ ULN, weekly monitoring is required, whereas in case of ALT elevation $>3 \times$ ULN, interruption of treatment is mandatory. Due to the complexity of the monitoring schedule, patients treated with teriflunomide had the lowest adherence to liver functions test monitoring compared with those treated with fingolimod or dimethyl fumarate in a Canadian observational study [113]. In 2021, product labelling was revised: biweekly ALT monitoring is required only in patients with pre-existing hepatic disorders, taking concomitant hepatotoxic drugs, or with symptoms suggestive of liver damage, otherwise it is required monthly during the first 6 months of treatment [114].

In the extension studies, safety data are available for up to 9 years and confirmed a drug discontinuation rate due to hepatic adverse events in $3-4 \%$ of patients $[115,116]$. Conversely, an observational study from Germany showed a $<1 \%$ drug discontinuation rate because of liver adverse events (Table 3) [117]. In 2020, the phase III trial of ofatumumab, which had teriflunomide treatment in the control arm, included 936 patients treated with teriflunomide for a median of 1.6 years and showed an incidence of hepatobiliary disorders $<2 \%$ [118].
In instances of suspected teriflunomide toxicity, elimination of the drug can be accelerated by cholestyramine or activated charcoal. Teriflunomide is eliminated slowly from the serum, probably due to enterohepatic recirculation. Without an accelerated elimination procedure using activated charcoal (50 g every $12 \mathrm{~h}$ for 11 days) or cholestyramine ( $8 \mathrm{~g}$ every $8 \mathrm{~h}$ for 11 days), drug levels can remain elevated for up to 8 months $[118,119]$.

Teriflunomide is contraindicated in cirrhotic patients with severe hepatic decompensation (Child C). A case of severe hypertriglyceridemia associated with teriflunomide treatment was reported, alongside another two cases with leflunomide, suggesting caution in the treatment of patients with fatty liver [120].

The risk of HBV reactivation in patients treated with teriflunomide has not been well assessed but is likely low (Table 4). In clinical trials, HBV screening was not universally performed, and no HBV cases were reported. Furthermore, leflunomide is not associated with high rates of HBV reactivation. No data on $\mathrm{HCV}$ patients treated with teriflunomide are available. In the TEMSO trial, a case of Cytomegalovirus hepatitis was reported in the teriflunomide arm, requiring drug interruption.

\subsection{Dimethyl Fumarate}

Dimethyl fumarate (BG-12) is a methylated, unsaturated dicarboxylic acid and was approved for treatment of MS in 2013. By activating the transcription factor nuclear-factorE2-related factor 2, the drug induces expression of endogenous antioxidative factors in brain cells, which may protect from the detrimental effect of reactive oxygen intermediates released as part of the inflammatory process in MS [121]. The dimethyl fumarate recommended dose is $120 \mathrm{mg}$ orally twice daily for 7 days, followed by a maintenance dose of $240 \mathrm{mg}$ twice daily [122]. During dimethyl fumarate treatment, white cells and lymphocyte counts are reduced by approximately $10 \%$ and $30 \%$ from baseline.

According to the phase III trials summarized in Table 1, abnormal liver function tests were reported in up to $50 \%$ of patients and were graded as moderate in $6 \%$ of patients and severe in $2 \%$ of patients $[57,123,124]$. In the extension study, safety data are available for up to 5 years and confirmed a drug discontinuation rate due to hepatic adverse events in 1-2\% of patients [125]. The hepatic adverse event profile was not different in patients previously treated with interferon beta [126].

Real-world observational studies from France [127], Spain [128], Germany [129], Denmark [130], and Italy [131-133] confirmed a discontinuation rate because of hepatic adverse events in $<1 \%$ of patients. Furthermore, an oral formulation of fumaric acid is labelled in Germany for treatment of chronic plaque psoriasis; moderate liver 
enzyme elevations were observed in $25 \%$ of patients in this setting [134].

In 2016, the first case report of severe acute liver injury associated with dimethyl fumarate was published [135]. An analysis of the FAERS database in the timeframe 2013-2016 collected 14 cases of clinically significant dimethyl fumarate-induced liver injury, 10 of which required hospitalization, and 7 fulfilled Hy's law criteria (Table 3). The most common presentation was a hepatocellular pattern with the majority of cases occurring within 1 month of treatment starting. Immunoallergic features and autoantibodies were not frequent, and all cases recovered after drug discontinuation [136]. The mechanism by which dimethyl fumarate causes liver injury is not known but is likely to be idiosyncratic. It is recommended to test serum levels of transaminases and total bilirubin before starting and during treatment with this medication (Table 5).

Patients with liver cirrhosis were excluded from dimethyl fumarate clinical trials. Dimethyl fumarate is extensively metabolized by serum and tissue esterases to monomethyl fumarate, further metabolized in the liver to fumarate which enters in the tricarboxylic acid cycle. Dimethyl fumarate metabolism is independent of the cytochrome P450 system. Therefore, in patients with liver cirrhosis, dimethyl fumarate therapy should be started with caution, without dose adjustments (Table 5).

Patients with active HBV or HCV infections were excluded from dimethyl fumarate clinical trials (but HBsAgnegative/anti-HBc-positive patients were not). The risk of $\mathrm{HBV}$ or HCV reactivation in patients treated with dimethyl fumarate has not been estimated but is likely low (Table 4). Recently, a peculiar case of HEV hepatitis in a patient treated with dimethyl fumarate has been reported in the literature [105].

\subsection{Cladribine}

Cladribine was approved in 2019 for the treatment of MS. Cladribine is a synthetic analog of adenosine, which is converted intracellularly to cladribine triphosphate, inhibiting DNA synthesis and repair, with subsequent induction of apoptosis. Cladribine preferentially affects lymphocytes because these cells are dependent on adenosine deaminase activity [137]. The cumulative recommended dose of cladribine is $3.5 \mathrm{mg} / \mathrm{kg}$ body weight over 2 years; it is administered orally for 2 weeks over 2 months as two annual courses. Each course consists of one or two 10-mg tablets (according to body weight) given once daily for 4 or 5 days. During cladribine treatment, lymphocyte count is reduced by approximately $50 \%$ from baseline.

According to the phase III trials, summarized in Table 1, abnormal liver function tests were uncommon and grade 3 transaminase elevation was reported in $<2 \%$ of patients
[138-141]. In the extension study, safety data are available for up to 4 years [142-144].

Liver function test monitoring during cladribine treatment is not required according to the drug label (Table 5). Liver metabolism of cladribine is negligible. Pharmacokinetics and safety studies in patients with liver cirrhosis have not been conducted (Table 5), and cladribine is not recommended in patients with moderate or severe decompensation (Child B or C). A case of new HBV infection in the Clarity extension trial was reported. Another case of HBV reactivation in an HBsAg-negative/anti-HBc-positive patient was reported in the setting of intravenous cladribine administration for treatment of chronic lymphocytic leukemia [145]. Cladribine is contraindicated in active viral hepatitis (Table 4).

\subsection{Natalizumab}

Natalizumab is a humanized neutralizing IgG4 $\mathrm{k}$ monoclonal antibody against leukocyte $\alpha 4$ integrin that blocks leukocyte adhesion to vascular cell adhesion molecule 1 receptor on endothelial cells, thus inhibiting their migration into the central nervous system [146]. Natalizumab was approved for MS treatment in 2004 and is administered at a dose of $300 \mathrm{mg}$ by intravenous infusion every 4 weeks [146].

According to the phase III trials summarized in Table 1, abnormal liver function tests were reported in $5 \%$ of patients and were graded as severe in $<1 \%$ of patients [147-149]. Safety data are available for up to 2 years of treatment in these trials; however, in extension studies up to 10 years, a rate of serious hepatobiliary adverse events was confirmed in $<1 \%$ of patients $[150,151]$.

Since 2010, six post-marketing cases of severe liver injury have been reported, prompting the addition of natalizumab-associated hepatic injury to the Warnings and Precautions section of product labelling [152]. The authors estimated the frequency of idiosyncratic clinically apparent liver injury from natalizumab to be 17 per 100,000 exposed patients. Hepatotoxicity can arise at any time during treatment, even after the first administration, and can show positive rechallenge.

Afterwards, severe cases of both natalizumab-induced liver injury and autoimmune hepatitis triggered by natalizumab have been reported, with many cases overlapping these two conditions and characterized by the presence of autoantibodies and a histological pattern of plasma cell infiltration, but without recurrence after steroid withdrawal [153-155]. No patient developed acute liver failure or progressed to chronic liver injury (Table 3). Currently, liver function test screening and monitoring are recommended, especially after the first three infusions, and quarterly thereafter (Table 5). Furthermore, patients should be instructed to 
seek medical attention for signs and symptoms that suggest liver damage, such as jaundice and vomiting.

Pharmacokinetics and safety studies in patients with liver cirrhosis have not been conducted, although it should be considered that the drug does not undergo hepatic metabolism and is found unmodified in urine (Table 5).

Patients with HBV and HCV infections were excluded from clinical trials with natalizumab. In this regard, it should be emphasized that natalizumab has been associated with a slightly increased risk of viral infections, particularly from the herpes virus family. A fatal case of HBV-related acute liver failure has been reported (although it is unclear if it was an acute HBV infection during natalizumab treatment or reactivation from a chronic HBV carrier state) [156]. Therefore, HBV- or HCV-infected patients who are candidates for treatment with natalizumab should be evaluated by a hepatologist before starting treatment (Table 4).

\subsection{Alemtuzumab}

Alemtuzumab is a humanized monoclonal IgG1 antibody that selectively targets CD52, an antigen highly expressed on $\mathrm{T}$ and $\mathrm{B}$ lymphocytes. Binding of alemtuzumab to CD52 results in depletion of circulating $\mathrm{T}$ and $\mathrm{B}$ cells, following which a distinct pattern of $\mathrm{T}$ - and $\mathrm{B}$-cell repopulation and a shift in cytokines toward a less inflammatory pattern occur [157]. Alemtuzumab was approved in 2014 for the treatment of relapsing MS and is also used in treatment of chronic lymphocytic leukemia. In the treatment of MS, the drug is administered intravenously over two courses: $12 \mathrm{mg} /$ day for 5 consecutive days, followed by the same dose for 3 consecutive days 12 months later; additional courses may be considered. Despite a drug half-life of less than a week [158], treatment results in a rapid depletion of circulating lymphocytes that can persist for several years; median recovery of CD4+ cells took 35 months [159], whilst B cells returned within 7 months but continued to rise, reaching $124 \%$ of baseline 27 months post-treatment [160].

According to the phase III trials summarized in Table 1, abnormal liver function tests occurred in $4 \%$ of patients and were graded as severe in $<1 \%$ of patients $[161,162]$. Safety data are available for up to 12 years of treatment in these trials [163-166]. After alemtuzumab infusion, ALT and $\gamma$-glutamyl transferase peaked $<3 \times$ ULN on day 5 and returned to normal in 30 days [167]. A case of severe DILI after alemtuzumab treatment with positive rechallenge was reported [168]. Data on cirrhotic patients are not available (Table 5).

Alemtuzumab treatment has been associated with onset of autoimmune disease, mainly through a mechanism of B-cell autoimmunity. More commonly, these conditions peak within 18-36 months after first infusion and include Graves' disease (reported in $~ 30 \%$ of patients treated with alemtuzumab) and, less commonly, autoimmune thrombocytopenia and Goodpasture syndrome [169, 170].

Interpreting lymphocyte reconstitution data from the pivotal phase III trials of alemtuzumab, Baker et al. have suggested that a more rapid CD19+ B-cell repopulation post-alemtuzumab, in the absence of T-cell regulatory mechanisms, might increase the risk of secondary autoimmunity [169]. According to the events reported post-marketing by the drug manufacturer, autoimmune hepatitis is a rare event, with an incidence of 10.7/10,000 patients treated with alemtuzumab [171, 172]. Two cases of alemtuzumabinduced acute liver failure have been reported in the literature; the first one was a patient with immune-mediated hepatitis requiring long-term immunosuppressive therapy, the other a patient with classic autoimmune hepatitis [173, 174]. Another case of fatal autoimmune hepatitis, probably alemtuzumab-related, was reported in the EudraVigilance database (Table 3) [175].

HBV and HCV reactivation have been described in patients with chronic lymphocytic leukemia treated with alemtuzumab, including some fatal cases of HBV reactivation [176]. As such patients were excluded from MS trials, the risk of these complications remains to be established in a neurological setting [177]. Extrapolating data from hematological patients, alemtuzumab therapy does have a high risk of $\mathrm{HBV}$ reactivation. In both $\mathrm{HBsAg}$-positive/ anti-HBc-positive patients and HBsAg-negative/anti-HBcpositive patients, antiviral prophylaxis is recommended for at least 6-12 months after the last dose [178, 179]. HCV exacerbation and possibly reactivation have also been described in patients receiving alemtuzumab therapy [180, 181]. Furthermore, cases of HEV-related acute hepatitis [182], cytomegalovirus-related hepatitis [183], and adenovirus hepatitis [184] after alemtuzumab therapy have been reported (Table 4).

\subsection{Ocrelizumab}

Ocrelizumab is a monoclonal IgG1 antibody that selectively targets CD20, depleting pre-B cells, mature B cells, and memory B cells without affecting lymphoid stem cells and plasma cells. Contrary to rituximab, ocrelizumab is a fully humanized antibody, designed to reduce immunogenicity [185]. Ocrelizumab was approved for treatment of MS in 2017 and is administered at a dose of $600 \mathrm{mg}$ by intravenous infusion every 24 weeks. Treatment results in rapid decline in circulating B cells and decrease in immunoglobulin levels, effects that persist for 6-18 months after last dose [185].

According to the phase III trials summarized in Table 1, abnormal liver function tests occurred in 1-2\% of patients. Safety data are available for up to 2.5 years of treatment in these trials. Only patients with mild hepatic impairment were included in clinical trials. Ocrelizumab is a monoclonal 
antibody eliminated by catabolism (i.e., degradation into peptides and amino acids) rather than by hepatic metabolism [186, 187]. Liver function tests are recommended before starting ocrelizumab treatment. Liver function test monitoring is not required but is suggested before every infusion (Table 5).

Similarly to other anti-CD20 antibody therapies, the most important risk for the liver is represented by HBV reactivation, which may be complicated with fulminant hepatitis, acute liver failure and death or need for emergency liver transplantation [179]. This condition can occur in patients with chronic hepatitis B (HBsAg positive/anti-HBc positive) as well as in patients with resolved HBV infection (HBsAg negative/anti-HBc positive). It is appropriate here to summarize previous experience with rituximab, which was approved in 1997 and is used to treat non-Hodgkin lymphoma and chronic lymphocytic leukemia as well as rheumatoid arthritis, vasculitis, and essential mixed cryoglobulinemia. In an onco-hematological setting, rituximab (frequently associated with cyclophosphamide, doxorubicin, vincristine, and prednisone in the R-CHOP schedule) has been associated with a risk of $\mathrm{HBV}$ reactivation of 30\%-60\% in HBsAg-positive/anti-HBc-positive patients and 13\%-22\% in $\mathrm{HBsAg}$-negative/anti-HBc-positive patients. Reactivation events may occur as late as 12 months after rituximab discontinuation, at a time when anti-HBs titers are waning [188]. In rheumatological patients, risk of HBV reactivation under rituximab therapy is less studied but is probably lower [189, 190]. Clinical guidelines suggest antiviral prophylaxis with entecavir or tenofovir (lamivudine only in HBsAg-negative/anti-HBc-positive patients), starting 7 days before the onset of rituximab and lasting 12-18 months after rituximab cessation. Liver function tests and HBV DNA should be tested every 3-6 months during prophylaxis and for at least 12 months after prophylaxis withdrawal as a large proportion of HBV reactivations develop after prophylaxis discontinuation [191, 192].

Data on ocrelizumab and risk of HBV reactivation are limited. In phase III trials, $\mathrm{HBsAg}$-positive patients were excluded but HBsAg-negative/anti-HBc-positive patients with undetectable HBV DNA were allowed; no cases of HBV infection were reported in MS trials [193]. In phase III trials in rheumatoid arthritis, ocrelizumab, and methotrexate combined therapy was associated with a single case of $\mathrm{HBV}$ reactivation, establishing an incidence of $1 / 300 \mathrm{HBsAg}-$ negative/HBcAb-positive patients (without prophylaxis) [194]. A single case report of HBV reactivation has been described in an $\mathrm{HBsAg}$-negative/HBcAb-positive patient on ocrelizumab treatment for MS (without HBV prophylaxis); the patient later was demonstrated to carry immuneescape mutations involving production of a defective HBsAg [195]. A single case report of fulminant hepatitis requiring emergency liver transplantation during treatment with ocrelizumab for MS was published, but this was associated with echovirus 25 , a member of the enterovirus family [196].

Consequently, HBV screening must be performed in all patients before starting treatment with ocrelizumab. Both HBsAg and $\mathrm{HBcAb}$ tests should be used. The presence of HBsAb does not prevent HBV reactivation, so the role for HBsAb screening before immunosuppressive therapy has not yet been established. For patients with positive HBV screening, hepatologist consultation is warranted. At present, chronic HBV hepatitis is considered a relative contraindication to the use of ocrelizumab in MS (Table 4).

\section{Diagnostic Work-Up in the Event of Elevated Liver Function Tests}

\subsection{Neurologist Work-Up}

How should a neurologist manage a patient with elevated liver function tests during treatment with DMTs? First, it is advisable to ask the patient about symptoms suggestive of liver damage: not only jaundice or dark urine, but it is also appropriate to interrogate the patient regarding nausea, vomiting, abdominal pain, fatigue, or anorexia. It is good clinical practice to instruct patients from the beginning of DMT treatment to inform the physician in case of onset of these symptoms. If the patient is symptomatic, treatment should be discontinued, and the patient referred to a hepatologist. If the patient is asymptomatic, the laboratory tests should be repeated after 1-2 weeks, depending on the extent of the elevation, to rule out an extrahepatic transient disease.

Confirmation or worsening of liver function test elevation should prompt physicians to request the first-level tests: viral serologies for HAV (IgM anti-HAV), HBV (HBsAg, IgM anti-HBc), HCV (anti-HCV), and HEV if available (IgM anti-HEV), autoantibodies (anti-nucleus, anti-mitochondria, anti-smooth muscle, anti-liver-kidney-microsomal antibodies), protein electrophoresis, and a hepatobiliary ultrasound. If a clear explanation for the elevation of liver function tests is found, the patient should be managed accordingly (e.g., infectious disease evaluation in case of acute hepatitis HAV, surgical evaluation in case of lithiasis of the biliary tract) and the possible interruption of DMT treatment should be discussed with the referring specialist [5]. A suggested algorithm to summarize the main steps of clinical management by the neurologist is presented in Table 6 .

\subsection{Hepatologist Work-Up}

If first-level tests are negative, the patient must be referred to a hepatologist who will proceed with second-level tests to exclude alcoholic hepatitis (detailed history and dosage of desialylated transferrin), a metabolic condition (presence 
Table 6 Clinical management of a patient with transaminase elevation during therapy with a disease-modifying treatment (DMT): algorithm for the neurologist

\begin{tabular}{|c|c|}
\hline $\begin{array}{l}\text { What to do in case of grade I transaminase elevation }(A L T<3 \times \\
U L N) ?\end{array}$ & $\begin{array}{l}\text { Always rule out symptoms suggestive of liver damage. If asymptomatic, } \\
\text { continue treatment and repeat transaminase biweekly. If alteration } \\
\text { persists over } 2-3 \text { months, request the first-level tests and consult } \\
\text { hepatologist }\end{array}$ \\
\hline $\begin{array}{l}\text { What to do in case of grade II transaminase elevation }(A L T>3 \text { to }<5 \\
\quad \times U L N) ?\end{array}$ & $\begin{array}{l}\text { Always rule out symptoms suggestive of liver damage. If asymptomatic, } \\
\text { continue treatment and repeat transaminase weekly. If alteration per- } \\
\text { sists over } 1 \text { month, request the first-level tests and consult hepatologist }\end{array}$ \\
\hline $\begin{array}{l}\text { What to do in case of grade III transaminase elevation ( }>5 \text { to }<20 \times \\
\text { ULN)? }\end{array}$ & Stop treatment, request the first-level tests and consult hepatologist \\
\hline What to do if the patient is symptomatic? & Stop treatment, request the first-level tests and consult hepatologist \\
\hline $\begin{array}{l}\text { What to ask the patient and what to investigate before referring to the } \\
\text { hepatologist? }\end{array}$ & $\begin{array}{l}\text { Ask the patient about symptoms suggestive of liver damage (jaundice, } \\
\text { dark urine, nausea, vomiting, abdominal pain, fatigue, anorexia) } \\
\text { Ask the patient about other potential cause of liver damage (alcohol } \\
\text { consumption, use of nonsteroidal anti-inflammatory drugs, aceta- } \\
\text { minophen or antibiotics, recent intake of seafood, mushrooms or } \\
\text { undercooked pork meat, fever or rash) }\end{array}$ \\
\hline What are the first-level viral serologies to request? & $\begin{array}{l}\text { Hepatitis A virus (HAV): IgM anti-HAV antibodies } \\
\text { Hepatitis B virus (HBV): HBsAg, IgM anti-HBc antibodies } \\
\text { Hepatitis C virus (HCV): anti-HCV antibodies } \\
\text { Hepatitis E virus (HEV): IgM anti-HEV antibodies }\end{array}$ \\
\hline What are the other first-level tests to request? & $\begin{array}{l}\text { Autoantibodies (anti-nucleus, anti-mitochondria, anti-smooth muscle, } \\
\text { anti-liver-kidney-microsomal antibodies) } \\
\text { Protein electrophoresis } \\
\text { Hepatobiliary ultrasound }\end{array}$ \\
\hline When to refer to hepatologist? & $\begin{array}{l}\text { Grade III transaminase elevation }(>5 \text { to }<20 \times \text { ULN) } \\
\text { Persistent grade I-II transaminase elevation of unexplained origin } \\
\text { Symptomatic patient } \\
\text { It is suggested to refer the patient after performing first-level tests }\end{array}$ \\
\hline
\end{tabular}

$A L T$ alanine aminotransferase, $U L N$ upper limit of normal

of steatosis on ultrasound and associated conditions such as diabetes and obesity), herpetic viral hepatitis (serologies for cytomegalovirus, Epstein Barr virus, herpes simplex virus if associated extrahepatic manifestations such as rash, lymphadenopathy, and atypical lymphocytes are present), celiac disease (dosage of anti-transglutaminase antibodies), vascular causes (suggested by hepatic ultrasound Doppler, a history of cardiac comorbidity, or previous episodes of hypotension or syncope), or possibly genetic diseases (dosage of ferritin, ceruloplasmin, cupremia, alpha-1antitrypsin). The hepatologist will also collect a detailed drug history to identify any concomitant agent; in some cases, liver injury is associated with concomitant symptomatic medications, like non-steroidal anti-inflammatory agents [197], supplements [198], or even herbal medicines [199]. The hepatologist will also evaluate whether to submit the patient to a liver biopsy. In general, liver biopsy is not required for diagnosis, but can be necessary to distinguish DILI from autoimmune hepatitis (interface hepatitis with portal lymphocytic or lymphoplasmacytic cells extending into the lobule, emperipolesis, and rosettes are considered typical, unless not specific, for autoimmune hepatitis), in case of atypical presentation (ascites, chronic hepatitis, microvesicular steatosis) or in case of negative or incomplete de-challenge. Finally, the hepatologist will perform the causality assessment by RUCAM; RUCAM score indicates if a drug is a possible $(3-5)$, probable $(6-8)$ or highly probable $(>8)$ cause of the liver injury [15]. A RUCAM score $>5$ consistently supports a diagnosis of DILI.

Some cases of DILI occur with autoimmune features, like autoantibody positivity and histological findings of interface hepatitis with portal and periportal infiltrates of lymphocytes, plasma cells, and eosinophils [200]. Furthermore, autoimmune hepatitis is not uncommon in patients with MS. According to a French observational study, the prevalence of autoimmune hepatitis is ten times higher in an MS cohort as compared with the general population (0.17 vs $0.02 \%)$ [201]. A recent literature review identified 40 reported cases of autoimmune hepatitis in patients with MS, but no patient was drug-naïve while autoimmune hepatitis occurred [202]. Differential diagnosis between drug-induced autoimmune hepatitis-like injury and true autoimmune hepatitis is challenging, and often the conclusive diagnostic confirmation comes only with the laboratory flare after glucocorticoid withdrawal, revealing autoimmune hepatitis [200]. 
Differentiation between these two conditions is extremely relevant to the neurologist. In the event of DILI, DMT treatment with the drug possibly or probably related to the liver injury must be permanently discontinued and never restarted. There is no cross-toxicity between DMTs, so previous hepatotoxicity does not influence the choice of subsequent treatments. In case of autoimmune hepatitis, the patient will need long-term treatment with immunosuppressants (e.g., prednisone and/or azathioprine), and this must be considered when choosing another treatment with DMTs. Beta-interferons, glatiramer acetate, natalizumab, and alemtuzumab are relatively contraindicated in autoimmune hepatitis due to the risk of disease exacerbation.

\section{Conclusions}

None of the DMTs currently available for the treatment of MS is free of potential hepatic toxic effects. Cases of acute liver failure have been reported for beta-interferon, fingolimod, natalizumab, alemtuzumab, and ocrelizumab by different mechanisms (idiosyncratic reaction, autoimmune hepatitis, or viral reactivation). Patients with MS should be informed about the possible hepatic complications of their treatment and should be educated to inform the physician about any onset of symptoms like jaundice, nausea, vomiting, abdominal pain, fatigue, or anorexia. Because most instances of DILI are idiosyncratic and independent of the dose and duration, it is not possible to predict or prevent them from occurring. The specific monitoring schedule for each DMT must be carefully observed, but unfortunately it is not proven that such strict monitoring prevents the rare occurrence of severe symptomatic cases. The clinician must pay particular attention to development, during DMT treatment, of clinical symptoms suggesting liver involvement. Some DMTs are contraindicated in cirrhotic patients or relatively contraindicated in autoimmune hepatitis, while hepatologist consultation is advisable before starting therapy in patients with chronic HBV or HCV hepatitis. Finally, since serious hepatic adverse events of medications are greatly underreported, it is important to report cases of serious liver-related adverse events in the literature with adequate causality documentation to better understand the liver safety profiles of DMTs.

Acknowledgements We thank Professor Paolo Calabresi for reading the manuscript and providing intellectual feedback.

\section{Declarations}

Funding Open access funding provided by Università Cattolica del Sacro Cuore within the CRUI-CARE Agreement.
Conflicts of interest A. Bianco reports personal fees and/or travel grants from Sanofi-Genzyme, Novartis, Merck, Roche, Biogen, Almirall. M. Lucchini reports travel grants from Roche, Biogen, Novartis, Almirall, and Sanofi-Genzyme; speaking and/or consulting fees from Biogen, Novartis, Merck-Serono, Sanofi-Genzyme, Bayer, and Almirall. M. Mirabella reports scientific advisory board membership with Bayer Schering, Biogen, Sanofi-Genzyme, Merck, Novartis, Teva; consulting and/or speaking fees, research support or travel grants from Almirall, Bayer Schering, Biogen, CSL Behring, Sanofi-Genzyme, Merck, Novartis, Teva, Roche, Ultragenix; principal investigator in clinical trials for Biogen, Merck, Novartis, Roche, Sanofi Genzyme, Teva, Ultragenix, and CSL Behring. Other authors declare no conflict of interests for this article.

Ethics approval Not applicable.

Consent Not applicable.

Availability of data and material Not applicable.

Author contributions $\mathrm{MB}$ and $\mathrm{AB}$ wrote the paper; $\mathrm{AB}$ and $\mathrm{ML}$ collected the data, AG, MM and AG reviewed the manuscript for important intellectual content. All authors read and approved the final version.

Open Access This article is licensed under a Creative Commons Attribution-NonCommercial 4.0 International License, which permits any non-commercial use, sharing, adaptation, distribution and reproduction in any medium or format, as long as you give appropriate credit to the original author(s) and the source, provide a link to the Creative Commons licence, and indicate if changes were made. The images or other third party material in this article are included in the article's Creative Commons licence, unless indicated otherwise in a credit line to the material. If material is not included in the article's Creative Commons licence and your intended use is not permitted by statutory regulation or exceeds the permitted use, you will need to obtain permission directly from the copyright holder. To view a copy of this licence, visit http://creativecommons.org/licenses/by-nc/4.0/.

\section{References}

1. Comi G, Radaelli M, Soelberg SP. Evolving concepts in the treatment of relapsing multiple sclerosis. Lancet (London, England). 2017;389(10076):1347-56.

2. Ontaneda D, Tallantyre E, Kalincik T, Planchon SM, Evangelou N. Early highly effective versus escalation treatment approaches in relapsing multiple sclerosis. Lancet Neurol. 2019;18(10):973-80.

3. Onakpoya IJ, Heneghan CJ, Aronson JK. Post-marketing withdrawal of 462 medicinal products because of adverse drug reactions: a systematic review of the world literature. BMC Med. 2016;4(14):10.

4. European Medicines Agency (EMA). 2018. https://www.ema. europa.eu/en/news/ema-review-zinbryta-confirms-medicinesrisks-outweigh-its-benefits.

5. EASL Clinical Practice Guidelines. Drug-induced liver injury. J Hepatol. 2019;70(6):1222-61.

6. Senior JR. Evolution of the Food and Drug Administration approach to liver safety assessment for new drugs: current status and challenges. Drug Saf. 2014;37(Suppl 1):S9-17.

7. Lewis JA. Post-marketing surveillance: how many patients? Trends Pharmacol Sci. 1981;2:93-4. 
8. Common Terminology Criteria for Adverse Events (CTCAE) Version 5.0; 2017. https://ctep.cancer.gov/protocoldevelopment/ electronic_applications/docs/ctcae_v5_quick_reference_5x7.pdf

9. Purkins L, Love ER, Eve MD, Wooldridge CL, Cowan C, Smart TS, et al. The influence of diet upon liver function tests and serum lipids in healthy male volunteers resident in a Phase I unit. Br J Clin Pharmacol. 2004;57(2):199-208.

10. Björnsson ES, Hoofnagle JH. Categorization of drugs implicated in causing liver injury: critical assessment based on published case reports. Hepatology. 2016;63(2):590-603.

11. Moiola L, Barcella V, Benatti S, Capobianco M, Capra R, Cinque $\mathrm{P}$, et al. The risk of infection in patients with multiple sclerosis treated with disease-modifying therapies: a Delphi consensus statement. Multiple Sclerosis J. 2020;17:1352458520952311.

12. Winkelmann A, Loebermann M, Reisinger EC, Hartung HP, Zettl UK. Disease-modifying therapies and infectious risks in multiple sclerosis. Nat Rev Neurol. 2016;12(4):217-33.

13. Riva A, Barcella V, Benatti SV, Capobianco M, Capra R, Cinque $\mathrm{P}$, et al. Vaccinations in patients with multiple sclerosis: a Delphi consensus statement. Multiple Sclerosis (Houndmills, Basingstoke, England). 2021;27(3):347-59.

14. Nociti V, Biolato M, De Fino C, Bianco A, Losavio FA, Lucchini $\mathrm{M}$, et al. Liver injury after pulsed methylprednisolone therapy in multiple sclerosis patients. Brain Behav. 2018;8(6):e00968.

15. Danan G, Benichou C. Causality assessment of adverse reactions to drugs-I. A novel method based on the conclusions of international consensus meetings: application to drug-induced liver injuries. J Clin Epidemiol. 1993;46(11):1323-30.

16. The IFNB Multiple Sclerosis Study Group. Interferon beta-1b is effective in relapsing-remitting multiple sclerosis. I. Clinical results of a multicenter, randomized, double-blind, placebocontrolled trial. Neurology. 1993;43(4):655-61.

17. Jacobs LD, Cookfair DL, Rudick RA, Herndon RM, Richert JR, Salazar AM, et al. Intramuscular interferon beta-1a for disease progression in relapsing multiple sclerosis. The Multiple Sclerosis Collaborative Research Group (MSCRG). Ann Neurol. 1996;39(3):285-94.

18. PRISMS (Prevention of Relapses and Disability by Interferon beta-1a Subcutaneously in Multiple Sclerosis) Study Group. Randomised double-blind placebo-controlled study of interferon beta-1a in relapsing/remitting multiple sclerosis. Lancet (London, England). 1998;352(9139):1498-504.

19. Panitch H, Goodin DS, Francis G, Chang P, Coyle PK, O'Connor $\mathrm{P}$, et al. Randomized, comparative study of interferon beta- $1 \mathrm{a}$ treatment regimens in MS: the EVIDENCE Trial. Neurology. 2002;59(10):1496-506.

20. Giovannoni G, Barbarash O, Casset-Semanaz F, King J, Metz L, Pardo G, et al. Safety and immunogenicity of a new formulation of interferon beta-1a (Rebif New Formulation) in a Phase IIIb study in patients with relapsing multiple sclerosis: 96-week results. Multiple Sclerosis (Houndmills, Basingstoke, England). 2009; 15(2):219-28.

21. Comi G, De Stefano N, Freedman MS, Barkhof F, Polman $\mathrm{CH}$, Uitdehaag BM, et al. Comparison of two dosing frequencies of subcutaneous interferon beta- $1 \mathrm{a}$ in patients with a first clinical demyelinating event suggestive of multiple sclerosis (REFLEX): a phase 3 randomised controlled trial. Lancet Neurol. 2012;11(1):33-41.

22. Secondary Progressive Efficacy Clinical Trial of Recombinant Interferon-Beta-1a in MS (SPECTRIMS) Study Group. Randomized controlled trial of interferon- beta-1a in secondary progressive MS: clinical results. Neurology. 2001;56(11):1496-504.

23. Andersen O, Elovaara I, Färkkilä M, Hansen HJ, Mellgren SI, Myhr KM, et al. Multicentre, randomised, double blind, placebo controlled, phase III study of weekly, low dose, subcutaneous interferon beta-1a in secondary progressive multiple sclerosis. J Neurol Neurosurg Psychiatry. 2004;75(5):706-10.

24. Kappos L, Polman CH, Freedman MS, Edan G, Hartung HP, Miller DH, et al. Treatment with interferon beta- $1 \mathrm{~b}$ delays conversion to clinically definite and McDonald MS in patients with clinically isolated syndromes. Neurology. 2006;67(7):1242-9.

25. Kieseier BC, Arnold DL, Balcer LJ, Boyko AA, Pelletier J, Liu $\mathrm{S}$, et al. Peginterferon beta-1a in multiple sclerosis: 2-year results from ADVANCE. Multiple Sclerosis (Houndmills, Basingstoke, England). 2015;21(8):1025-35.

26. Francis GS, Grumser Y, Alteri E, Micaleff A, O’Brien F, Alsop $\mathrm{J}$, et al. Hepatic reactions during treatment of multiple sclerosis with interferon-beta-1a: incidence and clinical significance. Drug Saf. 2003;26(11):815-27.

27. Tremlett HL, Yoshida EM, Oger J. Liver injury associated with the beta-interferons for MS: a comparison between the three products. Neurology. 2004;62(4):628-31.

28. Chan S, Kingwell E, Oger J, Yoshida E, Tremlett H. High-dose frequency beta-interferons increase the risk of liver test abnormalities in multiple sclerosis: a longitudinal study. Multiple Sclerosis (Houndmills, Basingstoke, England). 2011;17(3):361-7.

29. Kowalec K, Kingwell E, Yoshida EM, Marrie RA, Kremenchutzky M, Campbell TL, et al. Characteristics associated with drug-induced liver injury from interferon beta in multiple sclerosis patients. Expert Opin Drug Saf. 2014;13(10):1305-17.

30. Tremlett HL, Oger J. Elevated aminotransferases during treatment with interferon-beta for multiple sclerosis: actions and outcomes. Multiple Sclerosis (Houndmills, Basingstoke, England). 2004;10(3):298-301.

31. Bayas A, Rieckmann P. Managing the adverse effects of interferon-beta therapy in multiple sclerosis. Drug Saf. 2000;22(2):149-59.

32. Lublin FD, Whitaker JN, Eidelman BH, Miller AE, Arnason BG, Burks JS. Management of patients receiving interferon beta-1b for multiple sclerosis: report of a consensus conference. Neurology. 1996;46(1):12-8.

33. Walther EU, Hohlfeld R. Multiple sclerosis: side effects of interferon beta therapy and their management. Neurology. 1999;53(8):1622-7.

34. Christopher V, Scolding N, Przemioslo RT. Acute hepatitis secondary to interferon beta-1a in multiple sclerosis. J Neurol. 2005;252(7):855-6.

35. Grieco A, Montalto M, Vero V, Maria Vecchio F, Gasbarrini G. Severe acute hepatitis after resumption of interferon-Beta therapy for multiple sclerosis: a word of caution. Am J Gastroenterol. 2007;102(11):2606-7.

36. Mishra A, Guindi M, Kandel G, Streutker CJ. Autoimmune hepatitis-like reaction developing in a patient treated with interferon$\beta 1$ a. Histopathology. 2015;66(4):605-7.

37. Byrnes V, Afdhal N, Challies T, Greenstein PE. Drug induced liver injury secondary to interferon-beta (IFN-beta) in multiple sclerosis. Ann Hepatol. 2006;5(1):56-9.

38. Fontana RJ, Hayashi P, Bonkovsky HL, Kleiner DE, Kochhar S, $\mathrm{Gu}$ J, et al. Presentation and outcomes with clinically apparent interferon beta hepatotoxicity. Dig Dis Sci. 2013;58(6):1766-75.

39. Pulicken M, Koteish A, DeBusk K, Calabresi PA. Unmasking of autoimmune hepatitis in a patient with MS following interferon beta therapy. Neurology. 2006;66(12):1954-5.

40. Durelli L, Bongioanni MR, Ferrero B, Oggero A, Marzano A, Rizzetto M. Interferon treatment for multiple sclerosis: autoimmune complications may be lethal. Neurology. 1998;50(2):570-1.

41. Duchini A. Autoimmune hepatitis and interferon beta-1a for multiple sclerosis. Am J Gastroenterol. 2002;97(3):767-8. 
42. Wallack EM, Callon R. Liver injury associated with the betainterferons for MS. Neurology. 2004;63(6):1142-3 (author reply $-3)$.

43. Kowalec K, Yoshida EM, Traboulsee A, Carleton B, Tremlett $\mathrm{H}$. Suspected autoimmune hepatitis and primary biliary cirrhosis unmasked by interferon-beta in a multiple sclerosis patient. Multiple Sclerosis Related Disord. 2013;2(1):57-9.

44. Pietrosi G, Mandala L, Vizzini GB, Gruttadauria S, Minervini MI, Burgio G, et al. Fulminant hepatic failure and autoimmune disorders in patient with multiple sclerosis on interferon beta 1a: a fatal combination? Transplant Int. 2008;21(5):502-4.

45. Yoshida EM, Rasmussen SL, Steinbrecher UP, Erb SR, Scudamore $\mathrm{CH}$, Chung SW, et al. Fulminant liver failure during interferon beta treatment of multiple sclerosis. Neurology. 2001;56(10):1416.

46. Yamazaki Y, Suzuki A, Hirayanagi K, Tsukagoshi Y, Uehara $\mathrm{R}$, Horiguchi $\mathrm{K}$, et al. An autopsy case of fulminant hepatitis in a patient with multiple sclerosis treated by interferon-beta-1a. Internal Med (Tokyo, Japan). 2017;56(14):1897-901.

47. Kozielewicz D, Pawłowska M. Acute liver failure and liver transplantation in a patient with multiple sclerosis treated with interferon beta. Neurol Neurochir Pol. 2015;49(6):451-5.

48. Montero JL, Cerezo A, Fraga E, Barrera P, López-Cillero P, Costán $\mathrm{G}$, et al. Acute liver failure in a patient with multiple sclerosis treated with interferon-beta. Multiple Sclerosis (Houndmills, Basingstoke, England). 2007;13(6):820.

49. Villamil A, Mullen E, Casciato P, Gadano A. Interferon beta 1a-induced severe autoimmune hepatitis in patients with multiple sclerosis: report of two cases and review of the literature. Ann Hepatol. 2015;14(2):273-80.

50. Behrbohm J, Neid M, Stölzel U, Wittekind C, Hauss JP, Tillmann HL. Improvement of multiple sclerosis on tacrolimus plus mycophenolate mofetil after liver transplantation. Clinical improvement of multiple sclerosis in a patient requiring liver transplantation for acute liver failure following interferon-beta therapy. Transplant Int. 2007;20(12):1077-9.

51. Núñez O, de Andrés C, Alvarez E, García-Monzón C, Clemente G. Autoimmune hepatitis in patients with a diagnosis of multiple sclerosis. Gastroenterol Hepatol. 2004;27(9):521-4.

52. Tan FU, Cetinkaya H, Erden E, Ulkatan S, Aydin N. Dual benefit from intramuscular interferon-beta treatment in a patient with multiple sclerosis and chronic hepatitis-C virus infection. Hepatogastroenterology. 2002;49(48):1686-7.

53. Weber MS, Hohlfeld R, Zamvil SS. Mechanism of action of glatiramer acetate in treatment of multiple sclerosis. Neurotherapeutics. 2007;4(4):647-53.

54. Mikol DD, Barkhof F, Chang P, Coyle PK, Jeffery DR, Schwid SR, et al. Comparison of subcutaneous interferon beta-1a with glatiramer acetate in patients with relapsing multiple sclerosis (the REbif vs Glatiramer Acetate in Relapsing MS Disease [REGARD] study): a multicentre, randomised, parallel, openlabel trial. Lancet Neurol. 2008;7(10):903-14.

55. Comi G, Martinelli V, Rodegher M, Moiola L, Bajenaru O, Carra A, et al. Effect of glatiramer acetate on conversion to clinically definite multiple sclerosis in patients with clinically isolated syndrome (PreCISe study): a randomised, doubleblind, placebo-controlled trial. Lancet (London, England). 2009;374(9700):1503-11.

56. O'Connor P, Filippi M, Arnason B, Comi G, Cook S, Goodin $\mathrm{D}$, et al. 250 microg or 500 microg interferon beta- $1 \mathrm{~b}$ versus 20 mg glatiramer acetate in relapsing-remitting multiple sclerosis: a prospective, randomised, multicentre study. Lancet Neurol. 2009;8(10):889-97.

57. Fox RJ, Miller DH, Phillips JT, Hutchinson M, Havrdova E, Kita M, et al. Placebo-controlled phase 3 study of oral
BG-12 or glatiramer in multiple sclerosis. N Engl J Med. 2012;367(12):1087-97.

58. Ford C, Goodman AD, Johnson K, Kachuck N, Lindsey JW, Lisak R, et al. Continuous long-term immunomodulatory therapy in relapsing multiple sclerosis: results from the 15 -year analysis of the US prospective open-label study of glatiramer acetate. Multiple Sclerosis (Houndmills, Basingstoke, England). 2010;16(3):342-50.

59. Scott LJ. Glatiramer acetate: a review of its use in patients with relapsing-remitting multiple sclerosis and in delaying the onset of clinically definite multiple sclerosis. CNS Drugs. 2013;27(11):971-88.

60. Ziemssen T, Calabrese P, Penner IK, Apfel R. QualiCOP: realworld effectiveness, tolerability, and quality of life in patients with relapsing-remitting multiple sclerosis treated with glatiramer acetate, treatment-naïve patients, and previously treated patients. J Neurol. 2016;263(4):784-91.

61. Zecca C, Disanto G, Sacco R, Riccitelli GC, Gobbi C. Use of glatiramer acetate between 2010-2015: effectiveness, safety and reasons to start GA as first or second line treatment in Swiss multiple sclerosis patients. BMC Neurol. 2019;19(1):159.

62. Lebrun-Frenay C, Moulignier A, Pierrot-Deseilligny C, Benrabah $\mathrm{R}$, Moreau T, Lubetzki C, et al. Five-year outcome in the copaxone observatory: a nationwide cohort of patients with multiple sclerosis starting treatment with glatiramer acetate in France. J Neurol. 2019;266(4):888-901.

63. Debouverie M, Moreau T, Lebrun C, Heinzlef O, Brudon F, Msihid J. A longitudinal observational study of a cohort of patients with relapsing-remitting multiple sclerosis treated with glatiramer acetate. Eur J Neurol. 2007;14(11):1266-74.

64. FDA Adverse Event Reporting System (FAERS) Freedom of Information Act. http://www.fda.gov. Accessed 25 Oct 2013.

65. Antezana A, Herbert J, Park J, Kister I. Glatiramer acetateinduced acute hepatotoxicity in an adolescent with MS. Neurology. 2014;82(20):1846-7.

66. Onmez A, Eminler AT, Ergenç H, Baykara M, Uslan I, Tamer A. Drug-induced liver injury by glatiramer acetate used for treatment of multiple sclerosis: a case report. J Investig Med High Impact Case Rep. 2013;1(4):2324709613517493.

67. La Gioia S, Bacis G, Sonzogni A, Frigeni B, Conti MZ, Vedovello M, et al. Glatiramer acetate-induced hepatitis in a young female patient with multiple sclerosis. Multiple Sclerosis Related Disord. 2014;3(6):732-4.

68. Flaire A, Carra-Dalliere C, Ayrignac X, Blanc P, Labauge P. Glatiramer acetate-induced hepatitis in a patient with multiple sclerosis. Acta Neurol Belg. 2016;116(1):99-100.

69. Sinagra E, Raimondo D, Cottone S, Guddo F, Gabriele Rizzo A, Amvrosiadis G, et al. Does glatiramer acetate provoke hepatitis in multiple sclerosis? Multiple Sclerosis Related Disord. 2014;3(2):266-8.

70. Neumann H, Csepregi A, Sailer M, Malfertheiner P. Glatiramer acetate induced acute exacerbation of autoimmune hepatitis in a patient with multiple sclerosis. J Neurol. 2007;254(6):816-7.

71. von Kalckreuth V, Lohse AW, Schramm C. Unmasking autoimmune hepatitis under immunomodulatory treatment of multiple sclerosis-not only beta interferon. Am J Gastroenterol. 2008;103(8):2147-8 (author reply 8).

72. Almeida J, Solà-Valls N, Pose E, Blanco Y, Sepúlveda M, Llufriu $\mathrm{S}$, et al. Liver injury and glatiramer acetate, an uncommon association: case report and literature review. Ther Adv Neurol Disord. 2017;10(11):367-72.

73. Subramaniam K, Pavli P, Llewellyn H, Chitturi S. Glatiramer acetate induced hepatotoxicity. Curr Drug Saf. 2012;7(2):186-8.

74. Deltenre P, Peny MO, Dufour A, Nady ME, Henrion J. Acute hepatitis induced by glatiramer acetate. BMJ case reports. 2009;2009:bcr0920080913. 
75. Fernández Fernández N, Joao Matias D, Pisabarros Blanco C, Rodríguez Martín L, Aparicio Cabezudo M, Linares Torres P, et al. Hepatitis induced by glatiramer acetate. Gastroenterol Hepatol. 2015;38(4):280-1.

76. Makhani N, Ngan BY, Kamath BM, Yeh EA. Glatiramer acetateinduced acute hepatotoxicity in an adolescent with MS. Neurology. 2013;81(9):850-2.

77. Pelletier D, Hafler DA. Fingolimod for multiple sclerosis. N Engl J Med. 2012;366(4):339-47.

78. Boulton C, Meiser K, David OJ, Schmouder R. Pharmacodynamic effects of steady-state fingolimod on antibody response in healthy volunteers: a 4-week, randomized, placebo-controlled, parallel-group, multiple-dose study. J Clin Pharmacol. 2012;52(12):1879-90.

79. Kappos L, Radue EW, O'Connor P, Polman C, Hohlfeld $\mathrm{R}$, Calabresi $\mathrm{P}$, et al. A placebo-controlled trial of oral fingolimod in relapsing multiple sclerosis. N Engl J Med. 2010;362(5):387-401.

80. Cohen JA, Barkhof F, Comi G, Hartung HP, Khatri BO, Montalban X, et al. Oral fingolimod or intramuscular interferon for relapsing multiple sclerosis. N Engl J Med. 2010;362(5):402-15.

81. Calabresi PA, Radue EW, Goodin D, Jeffery D, Rammohan KW, Reder AT, et al. Safety and efficacy of fingolimod in patients with relapsing-remitting multiple sclerosis (FREEDOMS II): a double-blind, randomised, placebo-controlled, phase 3 trial. Lancet Neurol. 2014;13(6):545-56.

82. Lublin F, Miller DH, Freedman MS, Cree BAC, Wolinsky JS, Weiner $\mathrm{H}$, et al. Oral fingolimod in primary progressive multiple sclerosis (INFORMS): a phase 3, randomised, doubleblind, placebo-controlled trial. Lancet (London, England). 2016;387(10023):1075-84.

83. Chitnis T, Arnold DL, Banwell B, Brück W, Ghezzi A, Giovannoni $G$, et al. Trial of Fingolimod versus Interferon Beta-1a in Pediatric Multiple Sclerosis. N Engl J Med. 2018;379(11):1017-27.

84. Kappos L, O'Connor P, Radue EW, Polman C, Hohlfeld R, Selmaj K, et al. Long-term effects of fingolimod in multiple sclerosis: the randomized FREEDOMS extension trial. Neurology. 2015;84(15):1582-91.

85. Cohen JA, Khatri B, Barkhof F, Comi G, Hartung HP, Montalban X, et al. Long-term (up to 4.5 years) treatment with fingolimod in multiple sclerosis: results from the extension of the randomised TRANSFORMS study. J Neurol Neurosurg Psychiatry. 2016;87(5):468-75.

86. Cohen JA, Tenenbaum N, Bhatt A, Zhang Y, Kappos L. Extended treatment with fingolimod for relapsing multiple sclerosis: the 14-year LONGTERMS study results. Ther Adv Neurol Disord. 2019;12:1756286419878324.

87. Jin Y, Zollinger M, Borell H, Zimmerlin A, Patten CJ. CYP4F enzymes are responsible for the elimination of fingolimod (FTY720), a novel treatment of relapsing multiple sclerosis. Drug Metab Disposition Biol Fate Chem. 2011;39(2):191-8.

88. Kovarik JM, Schmouder RL, Hartmann S, Riviere GJ, Picard F, Voss B, et al. Fingolimod (FTY720) in severe hepatic impairment: pharmacokinetics and relationship to markers of liver function. J Clin Pharmacol. 2006;46(2):149-56.

89. Ziemssen T, Lang M, Tackenberg B, Schmidt S, Albrecht H, Klotz L, et al. Real-world persistence and benefit-risk profile of fingolimod over 36 months in Germany. Neurol(R) Neuroimmunol Neuroinflamm. 2019;6(3):e548.

90. Izquierdo G, Damas F, Páramo MD, Ruiz-Peña JL, Navarro G. The real-world effectiveness and safety of fingolimod in relapsing-remitting multiple sclerosis patients: an observational study. PLoS ONE. 2017;12(4):e0176174.

91. Barrero F, Mallada-Frechin J, Martínez-Ginés ML, Marzo ME, Meca-Lallana V, Izquierdo G, et al. Spanish real-world experience with fingolimod in relapsing-remitting multiple sclerosis patients: MS NEXT study. PLoS ONE. 2020;15(4):e0230846.

92. Laroni A, Brogi D, Brescia Morra V, Guidi L, Pozzilli C, Comi $\mathrm{G}$, et al. Safety and tolerability of fingolimod in patients with relapsing-remitting multiple sclerosis: results of an open-label clinical trial in Italy. Neurol Sci. 2017;38(1):53-9.

93. Yamout BI, Zeineddine MM, Tamim H, Khoury SJ. Safety and efficacy of fingolimod in clinical practice: the experience of an academic center in the Middle East. J Neuroimmunol. 2015;15(289):93-7.

94. Achiron A, Aref H, Inshasi J, Harb M, Alroughani R, Bijarnia $\mathrm{M}$, et al. Effectiveness, safety and health-related quality of life of multiple sclerosis patients treated with fingolimod: results from a 12-month, real-world, observational PERFORMS study in the Middle East. BMC Neurol. 2017;17(1): 150.

95. Al-Hashel J, Ahmed SF, Behbehani R, Alroughani R. Real-world use of fingolimod in patients with relapsing remitting multiple sclerosis: a retrospective study using the national multiple sclerosis registry in Kuwait. CNS Drugs. 2014;28(9):817-24.

96. Patrucco L, Cristiano E, Sánchez F, Miguez J, Rojas JI. Realworld effectiveness and safety of fingolimod in patients with relapsing remitting multiple sclerosis: a prospective analysis in Buenos Aires, Argentina. Clin Neuropharmacol. 2019;42(5):163-6.

97. Ribeiro de Barros AH, Fiadeiro Sequeira JP, Lopes de Sousa AS, Cheganças Capela CM, Gomes Pedrosa RM, Dos Santos Manita MA. Safety and effectiveness of fingolimod in real-world multiple sclerosis portuguese patients. Clin Neuropharmacol. 2018;41(4):129-35.

98. Manni A, Direnzo V, Iaffaldano A, Di Lecce V, Tortorella C, Zoccolella $\mathrm{S}$, et al. Gender differences in safety issues during Fingolimod therapy: Evidence from a real-life Relapsing Multiple Sclerosis cohort. Brain Behav. 2017;7(10):e00804.

99. Yamout BI, Zeineddine MM, Sawaya RA, Khoury SJ. Safety and efficacy of reduced fingolimod dosage treatment. J Neuroimmunol. 2015;15(285):13-5.

100. Buckle A, Sood S. Fingolimod: a tale of two livers. J Gastroenterol Hepatol. 2016;31:94.

101. https://www.ema.europa.eu/en/medicines/dhpc/gilenya-fingo limod-updated-recommendations-minimise-risk-drug-inducedliver-injury-dili. Accessed 10 Nov 2020

102. https://www.aifa.gov.it/documents/20142/1097058/2020.11.10_ NII_su_Gilenya_IT.pdf. Accessed 10 Nov 2020

103. Tagawa A, Ogawa T, Tetsuka S, Otsuka M, Hashimoto R, Kato $\mathrm{H}$, et al. Hepatitis $\mathrm{C}$ virus ( $\mathrm{HCV}$ ) reactivation during fingolimod treatment for relapsing and remitting multiple sclerosis. Multiple Sclerosis Related Disord. 2016;9:155-7.

104. Memon A, Miranda J. Hepatitis E virus infection in a patient with suspected drug-induced liver injury. BMJ Case Rep. 2017;31:2017.

105. Diebold M, Fischer-Barnicol B, Tsagkas C, Kuhle J, Kappos L, Derfuss T, et al. Hepatitis E virus infections in patients with MS on oral disease-modifying treatment. Neurol(R) Neuroimmunol Neuroinflamm. 2019;6(5):e594.

106. Chen EY, Baum K, Collins W, Löve A, Merz M, Olafsson S, et al. Hepatitis E masquerading as drug-induced liver injury. Hepatology. 2012;56(6):2420-3.

107. Warnke C, Stüve O, Kieseier BC. Teriflunomide for the treatment of multiple sclerosis. Clin Neurol Neurosurg. 2013;115(Suppl 1):S90-4.

108. Garnock-Jones KP. Teriflunomide: a review of its use in relapsing multiple sclerosis. CNS Drugs. 2013;27(12):1103-23.

109. O'Connor P, Wolinsky JS, Confavreux C, Comi G, Kappos L, Olsson TP, et al. Randomized trial of oral 
teriflunomide for relapsing multiple sclerosis. $\mathrm{N}$ Engl J Med. 2011;365(14):1293-303.

110. Confavreux C, O'Connor P, Comi G, Freedman MS, Miller $\mathrm{AE}$, Olsson TP, et al. Oral teriflunomide for patients with relapsing multiple sclerosis (TOWER): a randomised, double-blind, placebo-controlled, phase 3 trial. Lancet Neurol. 2014;13(3):247-56.

111. Miller AE, Wolinsky JS, Kappos L, Comi G, Freedman MS, Olsson TP, et al. Oral teriflunomide for patients with a first clinical episode suggestive of multiple sclerosis (TOPIC): a randomised, double-blind, placebo-controlled, phase 3 trial. Lancet Neurol. 2014;13(10):977-86.

112. Vermersch P, Czlonkowska A, Grimaldi LM, Confavreux C, Comi G, Kappos L, et al. Teriflunomide versus subcutaneous interferon beta-1a in patients with relapsing multiple sclerosis: a randomised, controlled phase 3 trial. Multiple Sclerosis (Houndmills, Basingstoke, England). 2014;20(6):705-16.

113. Ng HS, Kingwell E, Zhu F, Zhang T, Marrie RA, Carruthers R, et al. Adherence to laboratory monitoring among people taking oral drugs for multiple sclerosis: a Canadian population-based study. Multiple Sclerosis (Houndmills, Basingstoke, England). 2020;6:1352458520910500.

114. https://www.ema.europa.eu/en/documents/product-information/ aubagio-epar-product-information_en.pdf. Accessed 1 Mar 2021.

115. O'Connor P, Comi G, Freedman MS, Miller AE, Kappos L, Bouchard JP, et al. Long-term safety and efficacy of teriflunomide: Nine-year follow-up of the randomized TEMSO study. Neurology. 2016;86(10):920-30.

116. Confavreux C, Li DK, Freedman MS, Truffinet P, Benzerdjeb H, Wang D, et al. Long-term follow-up of a phase 2 study of oral teriflunomide in relapsing multiple sclerosis: safety and efficacy results up to 8.5 years. Multiple Sclerosis (Houndmills, Basingstoke, England). 2012;18(9):1278-89.

117. Kallmann BA, Tiel-Wilck K, Kullmann JS, Engelmann U, Chan A. Real-life outcomes of teriflunomide treatment in patients with relapsing multiple sclerosis: TAURUS-MS observational study. Multiple Sclerosis (Houndmills, Basingstoke, England). 2019; 12:1756286419835077.

118. Hauser SL, Bar-Or A, Cohen JA, Comi G, Correale J, Coyle PK, et al. Ofatumumab versus teriflunomide in multiple sclerosis. $\mathrm{N}$ Engl J Med. 2020;383(6):546-57.

119. Miller AE. Teriflunomide: a once-daily oral medication for the treatment of relapsing forms of multiple sclerosis. Clin Ther. 2015;37(10):2366-80.

120. Camara-Lemarroy CR, Castilló J, Sastre-Garriga J, Tintore M, Montalban X. Severe hypertriglyceridemia associated with teriflunomide in a patient with multiple sclerosis: a case report. Multiple Sclerosis (Houndmills, Basingstoke, England). 2018;24(10):1383-5.

121. Sorensen PS, Sellebjerg F. Oral fumarate for relapsingremitting multiple sclerosis. Lancet (London, England). 2008;372(9648):1447-8.

122. Sheremata W, Brown AD, Rammohan KW. Dimethyl fumarate for treating relapsing multiple sclerosis. Expert Opin Drug Saf. 2015;14(1):161-70.

123. Gold R, Kappos L, Arnold DL, Bar-Or A, Giovannoni G, Selmaj K, et al. Placebo-controlled phase 3 study of oral BG-12 for relapsing multiple sclerosis. N Engl J Med. 2012;367(12):1098-107.

124. Saida T, Yamamura T, Kondo T, Yun J, Yang M, Li J, et al. A randomized placebo-controlled trial of delayed-release dimethyl fumarate in patients with relapsing-remitting multiple sclerosis from East Asia and other countries. BMC Neurol. 2019;19(1):5.

125. Gold R, Arnold DL, Bar-Or A, Hutchinson M, Kappos L, Havrdova $\mathrm{E}$, et al. Long-term effects of delayed-release dimethyl fumarate in multiple sclerosis: Interim analysis of ENDORSE, a randomized extension study. Multiple Sclerosis (Houndmills, Basingstoke, England). 2017;23(2):253-65.

126. Fernández Ó, Giovannoni G, Fox RJ, Gold R, Phillips JT, Potts J, et al. Efficacy and safety of delayed-release dimethyl fumarate for relapsing-remitting multiple sclerosis in prior interferon users: an integrated analysis of DEFINE and CONFIRM. Clin Ther. 2017;39(8):1671-9.

127. Condé S, Moisset X, Pereira B, Zuel M, Colamarino R, MailletVioud M, et al. Dimethyl fumarate and teriflunomide for multiple sclerosis in a real-life setting: a French retrospective cohort study. Eur J Neurol. 2019;26(3):460-7.

128. Sabin J, Urtiaga S, Pilo B, Thuissard I, Galan V, Sainz de la Maza $\mathrm{S}$, et al. Tolerability and safety of dimethyl fumarate in relapsing multiple sclerosis: a prospective observational multicenter study in a real-life Spanish population. J Neurol. 2020;267:2367-71.

129. Miclea A, Leussink VI, Hartung HP, Gold R, Hoepner R. Safety and efficacy of dimethyl fumarate in multiple sclerosis: a multicenter observational study. J Neurol. 2016;263(8):1626-32.

130. Sejbaek T, Nybo M, Petersen T, Illes Z. Real-life persistence and tolerability with dimethyl fumarate. Multiple Sclerosis Related Disord. 2018;24:42-6.

131. Mirabella M, Prosperini L, Lucchini M, Boffa L, Borriello G, Buscarinu MC, et al. Safety and efficacy of dimethyl fumarate in multiple sclerosis: an italian, multicentre, Real-World Study. CNS Drugs. 2018;32(10):963-70.

132. Mallucci G, Annovazzi P, Miante S, Torri-Clerici V, Matta M, La Gioia $S$, et al. Two-year real-life efficacy, tolerability and safety of dimethyl fumarate in an Italian multicentre study. J Neurol. 2018;265(8):1850-9.

133. Lanzillo R, Moccia M, Palladino R, Signoriello E, Carotenuto A, Maniscalco GT, et al. Clinical predictors of Dimethyl Fumarate response in multiple sclerosis: a real life multicentre study. Multiple Sclerosis Related Disord. 2020;38:101871.

134. Hoefnagel JJ, Thio HB, Willemze R, Bouwes Bavinck JN. Longterm safety aspects of systemic therapy with fumaric acid esters in severe psoriasis. Br J Dermatol. 2003;149(2):363-9.

135. Jüngst C, Kim YJ, Lammert F. Severe drug-induced liver injury related to therapy with dimethyl fumarate. Hepatology. 2016;64(4):1367-9.

136. Muñoz MA, Kulick CG, Kortepeter CM, Levin RL, Avigan MI. Liver injury associated with dimethyl fumarate in multiple sclerosis patients. Multiple Sclerosis (Houndmills, Basingstoke, England). 2017;23(14):1947-9.

137. Rammohan K, Coyle PK, Sylvester E, Galazka A, Dangond F, Grosso M, et al. The development of cladribine tablets for the treatment of multiple sclerosis: a comprehensive review. Drugs. 2020;80(18):1901-28.

138. Giovannoni G, Comi G, Cook S, Rammohan K, Rieckmann $\mathrm{P}$, Soelberg Sørensen P, et al. A placebo-controlled trial of oral cladribine for relapsing multiple sclerosis. N Engl J Med. 2010;362(5):416-26.

139. Cook S, Vermersch P, Comi G, Giovannoni G, Rammohan K, Rieckmann P, et al. Safety and tolerability of cladribine tablets in multiple sclerosis: the CLARITY (CLAdRIbine Tablets treating multiple sclerosis orallY) study. Multiple Sclerosis (Houndmills, Basingstoke, England). 2011;17(5):578-93.

140. Leist TP, Comi G, Cree BA, Coyle PK, Freedman MS, Hartung HP, et al. Effect of oral cladribine on time to conversion to clinically definite multiple sclerosis in patients with a first demyelinating event (ORACLE MS): a phase 3 randomised trial. Lancet Neurol. 2014;13(3):257-67.

141. Montalban X, Leist TP, Cohen BA, Moses H, Campbell J, Hicking $\mathrm{C}$, et al. Cladribine tablets added to IFN- $\beta$ in active relapsing MS: the ONWARD study. Neurol(R) Neuroimmunol Neuroinflamm. 2018;5(5):e477. 
142. Giovannoni G, Soelberg Sorensen P, Cook S, Rammohan K, Rieckmann P, Comi G, et al. Safety and efficacy of cladribine tablets in patients with relapsing-remitting multiple sclerosis: Results from the randomized extension trial of the CLARITY study. Multiple Sclerosis (Houndmills, Basingstoke, England). 2018;24(12):1594-604.

143. Cook S, Leist T, Comi G, Montalban X, Giovannoni G, Nolting A, et al. Safety of cladribine tablets in the treatment of patients with multiple sclerosis: an integrated analysis. Multiple Sclerosis Related Disord. 2019;29:157-67.

144. Leist T, Cook S, Comi G, Montalban X, Giovannoni G, Nolting A, et al. Long-term safety data from the cladribine tablets clinical development program in multiple sclerosis. Multiple Sclerosis Related Disord. 2020;46:102572.

145. Busuttil DP, Chasty RC, Fraser M, Copplestone JA, Prentice AG. Delayed reactivation of hepatitis $B$ infection after cladribine. Lancet (London, England). 1996;348(9020):129.

146. Ransohoff RM. Natalizumab for multiple sclerosis. N Engl J Med. 2007;356(25):2622-9.

147. Polman CH, O'Connor PW, Havrdova E, Hutchinson M, Kappos L, Miller DH, et al. A randomized, placebo-controlled trial of natalizumab for relapsing multiple sclerosis. N Engl J Med. 2006;354(9):899-910.

148. Rudick RA, Stuart WH, Calabresi PA, Confavreux C, Galetta SL, Radue EW, et al. Natalizumab plus interferon beta-1a for relapsing multiple sclerosis. N Engl J Med. 2006;354(9):911-23.

149. Kapoor R, Ho PR, Campbell N, Chang I, Deykin A, Forrestal $\mathrm{F}$, et al. Effect of natalizumab on disease progression in secondary progressive multiple sclerosis (ASCEND): a phase 3, randomised, double-blind, placebo-controlled trial with an openlabel extension. Lancet Neurol. 2018;17(5):405-15.

150. O’Connor P, Goodman A, Kappos L, Lublin F, Polman C, Rudick RA, et al. Long-term safety and effectiveness of natalizumab redosing and treatment in the STRATA MS Study. Neurology. 2014;83(1):78-86.

151. Butzkueven H, Kappos L, Wiendl H, Trojano M, Spelman T, Chang I, et al. Long-term safety and effectiveness of natalizumab treatment in clinical practice: 10 years of real-world data from the Tysabri Observational Program (TOP). J Neurol Neurosurg Psychiatry. 2020;91(6):660-8.

152. Bezabeh S, Flowers CM, Kortepeter C, Avigan M. Clinically significant liver injury in patients treated with natalizumab. Aliment Pharmacol Ther. 2010;31(9):1028-35.

153. Lisotti A, Azzaroli F, Brillanti S, Mazzella G. Severe acute autoimmune hepatitis after natalizumab treatment. Dig Liver Dis. 2012;44(4):356-7.

154. Antezana A, Sigal S, Herbert J, Kister I. Natalizumab-induced hepatic injury: a case report and review of literature. Multiple Sclerosis Related Disord. 2015;4(6):495-8.

155. Martínez-Lapiscina EH, Lacruz F, Bolado-Concejo F, Rodríguez-Pérez I, Ayuso T, Garaigorta M, et al. Natalizumabinduced autoimmune hepatitis in a patient with multiple sclerosis. Multiple Sclerosis (Houndmills, Basingstoke, England). 2013;19(9):1234-5.

156. Hillen ME, Cook SD, Samanta A, Grant E, Quinless JR, Rajasingham JK. Fatal acute liver failure with hepatitis B virus infection during nataluzimab treatment in multiple sclerosis. Neurol(R) Neuroimmunol Neuroinflamm. 2015;2(2):e72.

157. Coles AJ, Compston DA, Selmaj KW, Lake SL, Moran S, Margolin $\mathrm{DH}$, et al. Alemtuzumab vs. interferon beta-1a in early multiple sclerosis. New Engl J Med. 2008;359(17):1786-801.

158. Hale G, Rebello P, Brettman LR, Fegan C, Kennedy B, Kimby E, et al. Blood concentrations of alemtuzumab and antiglobulin responses in patients with chronic lymphocytic leukemia following intravenous or subcutaneous routes of administration. Blood. 2004;104(4):948-55.
159. Hill-Cawthorne GA, Button T, Tuohy O, Jones JL, May K, Somerfield $\mathrm{J}$, et al. Long term lymphocyte reconstitution after alemtuzumab treatment of multiple sclerosis. J Neurol Neurosurg Psychiatry. 2012;83(3):298-304.

160. Costelloe L, Jones J, Coles A. Secondary autoimmune diseases following alemtuzumab therapy for multiple sclerosis. Expert Rev Neurother. 2012;12(3):335-41.

161. Cohen JA, Coles AJ, Arnold DL, Confavreux C, Fox EJ, Hartung $\mathrm{HP}$, et al. Alemtuzumab versus interferon beta $1 \mathrm{a}$ as first-line treatment for patients with relapsing-remitting multiple sclerosis: a randomised controlled phase 3 trial. Lancet (London, England). 2012;380(9856):1819-28.

162. Coles AJ, Twyman CL, Arnold DL, Cohen JA, Confavreux C, Fox EJ, et al. Alemtuzumab for patients with relapsing multiple sclerosis after disease-modifying therapy: a randomised controlled phase 3 trial. Lancet (London, England). 2012;380(9856):1829-39.

163. Havrdova E, Arnold DL, Cohen JA, Hartung HP, Fox EJ, Giovannoni $\mathrm{G}$, et al. Alemtuzumab CARE-MS I 5-year follow-up: Durable efficacy in the absence of continuous MS therapy. Neurology. 2017;89(11):1107-16.

164. Coles AJ, Cohen JA, Fox EJ, Giovannoni G, Hartung HP, Havrdova E, et al. Alemtuzumab CARE-MS II 5-year follow-up: Efficacy and safety findings. Neurology. 2017;89(11):1117-26.

165. Ziemssen T, Bass AD, Berkovich R, Comi G, Eichau S, Hobart $\mathrm{J}$, et al. Efficacy and safety of alemtuzumab through 9 years of follow-up in patients with highly active disease: post hoc analysis of CARE-MS I and II patients in the TOPAZ extension study. CNS Drugs. 2020;34(9):973-88.

166. Steingo B, Al Malik Y, Bass AD, Berkovich R, Carraro M, Fernández Ó, et al. Long-term efficacy and safety of alemtuzumab in patients with RRMS: 12-year follow-up of CAMMS223. J Neurol. 2020;267(11):3343-53.

167. Thomas K, Eisele J, Rodriguez-Leal FA, Hainke U, Ziemssen T. Acute effects of alemtuzumab infusion in patients with active relapsing-remitting MS. Neurol(R) Neuroimmunol Neuroinflamm. 2016;3(3):e228.

168. Beattie W, Yan B, Sood S. Acute severe hepatitis with alemtuzumab and rechallenge after a year. J Clin Neurosci. 2019;60:158-60.

169. Baker D, Herrod SS, Alvarez-Gonzalez C, Giovannoni G, Schmierer K. Interpreting lymphocyte reconstitution data from the pivotal phase 3 trials of alemtuzumab. JAMA Neurol. 2017;74(8):961-9.

170. Devonshire V, Phillips R, Wass H, Da Roza G, Senior P. Monitoring and management of autoimmunity in multiple sclerosis patients treated with alemtuzumab: practical recommendations. J Neurol 2018;265(11):2494-505

171. Hartung HP, Mares J, Barnett MH. Alemtuzumab: rare serious adverse events of a high-efficacy drug. Multiple Sclerosis (Houndmills, Basingstoke, England). 2020;26(6):737-40.

172. Willis MD, Harding KE, Pickersgill TP, Wardle M, Pearson OR, Scolding NJ, et al. Alemtuzumab for multiple sclerosis: long term follow-up in a multi-centre cohort. Multiple Sclerosis (Houndmills, Basingstoke, England). 2016;22(9):1215-23.

173. Bolte FJ, Schmidt HH, Schlevogt B. Immune-mediated hepatitis induced by therapy with alemtuzumab in a patient with multiple sclerosis. Hepatology. 2020;73:460-3.

174. El Sankari S, Dahlqvist G, Monino L, van Pesch V. Auto-immune hepatitis in a patient with multiple sclerosis treated with alemtuzumab. Acta Neurol Belg. 2018;118(2):331-3.

175. Holmøy T, Fevang B, Olsen DB, Spigset O, Bø L. Adverse events with fatal outcome associated with alemtuzumab treatment in multiple sclerosis. BMC Res Notes. 2019;12(1):497.

176. Moses SE, Lim ZY, Sudhanva M, Devereux S, Ho AY, Pagliuca A, et al. Lamivudine prophylaxis and treatment of hepatitis B 
Virus-exposed recipients receiving reduced intensity conditioning hematopoietic stem cell transplants with alemtuzumab. J Med Virol. 2006;78(12):1560-3.

177. Mikulska M, Lanini S, Gudiol C, Drgona L, Ippolito G, Fernández-Ruiz M, et al. ESCMID Study Group for Infections in Compromised Hosts (ESGICH) Consensus Document on the safety of targeted and biological therapies: an infectious diseases perspective (Agents targeting lymphoid cells surface antigens [I]: CD19, CD20 and CD52). Clin Microbiol Infect. 2018;24(Suppl 2):S71-s82.

178. Iannitto E, Minardi V, Calvaruso G, Mulè A, Ammatuna E, Di Trapani R, et al. Hepatitis B virus reactivation and alemtuzumab therapy. Eur J Haematol. 2005;74(3):254-8.

179. Loomba R, Liang TJ. Hepatitis B reactivation associated with immune suppressive and biological modifier therapies: current concepts, management strategies, and future directions. Gastroenterology. 2017;152(6):1297-309.

180. Anoop P, Wotherspoon A, Matutes E. Severe liver dysfunction from hepatitis $\mathrm{C}$ virus reactivation following alemtuzumab treatment for chronic lymphocytic leukaemia. Br J Haematol. 2010;148(3):484-6.

181. Dizdar O, Tapan U, Aksoy S, Harputluoglu H, Kilickap S, Barista I. Liver dysfunction after chemotherapy in lymphoma patients infected with hepatitis C. Eur J Haematol. 2008;80(5):381-5.

182. di Ioia M, Di Stefano V, Farina D, Di Tommaso V, Travaglini D, Pietrolongo E, et al. Alemtuzumab treatment of multiple sclerosis in real-world clinical practice: a report from a single Italian center. Multiple Sclerosis Related Disord. 2020;38:101504.

183. Barone S, Scannapieco S, Torti C, Filippelli E, Pisani V, Granata A, et al. Hepatic microabscesses during CMV reactivation in a multiple sclerosis patient after alemtuzumab treatment. Multiple Sclerosis Related Disord. 2018;20:6-8.

184. Putra J, Suriawinata AA. Adenovirus hepatitis presenting as tumoral lesions in an immunocompromised patient. Ann Hepatol. 2014;13(6):827-9.

185. Calabresi PA. B-cell depletion - a frontier in monoclonal antibodies for multiple sclerosis. N Engl J Med. 2017;376(3):280-2.

186. Hauser SL, Bar-Or A, Comi G, Giovannoni G, Hartung HP, Hemmer B, et al. Ocrelizumab versus interferon beta-1a in relapsing multiple sclerosis. N Engl J Med. 2017;376(3):221-34.

187. Montalban X, Hauser SL, Kappos L, Arnold DL, Bar-Or A, Comi $\mathrm{G}$, et al. Ocrelizumab versus placebo in primary progressive multiple sclerosis. N Engl J Med. 2017;376(3):209-20.

188. Perrillo RP, Gish R, Falck-Ytter YT. American Gastroenterological Association Institute technical review on prevention and treatment of hepatitis B virus reactivation during immunosuppressive drug therapy. Gastroenterology. 2015;148(1):221-44.e3.

189. Nard FD, Todoerti M, Grosso V, Monti S, Breda S, Rossi S, et al. Risk of hepatitis B virus reactivation in rheumatoid arthritis patients undergoing biologic treatment: extending perspective from old to newer drugs. World J Hepatol. 2015;7(3):344-61.

190. Varisco V, Viganò M, Batticciotto A, Lampertico P, Marchesoni A, Gibertini P, et al. Low risk of hepatitis B virus reactivation in HBsAg-negative/Anti-HBc-positive carriers receiving rituximab for rheumatoid arthritis: a retrospective multicenter Italian study. J Rheumatol. 2016;43(5):869-74.

191. Terrault NA, Lok ASF, McMahon BJ, Chang KM, Hwang JP, Jonas MM, et al. Update on prevention, diagnosis, and treatment of chronic hepatitis B: AASLD 2018 hepatitis B guidance. Hepatology. 2018;67(4):1560-99.

192. Lampertico P, Agarwal K, Berg T, Buti M, Janssen HLA, Papatheodoridis G, Zoulim F, Tacke F. EASL 2017 Clinical Practice Guidelines on the management of hepatitis B virus infection. $\mathrm{J}$ Hepatol. 2017;67(2):370-98.

193. Epstein DJ, Dunn J, Deresinski S. Infectious complications of multiple sclerosis therapies: implications for screening, prophylaxis, and management. Open Forum Infect Dis. 2018;5(8):174.

194. Emery P, Rigby W, Tak PP, Dörner T, Olech E, Martin C, et al. Safety with ocrelizumab in rheumatoid arthritis: results from the ocrelizumab phase III program. PLoS ONE. 2014;9(2):e87379.

195. Ciardi MR, Iannetta M, Zingaropoli MA, Salpini R, Aragri M, Annecca R, et al. Reactivation of hepatitis B virus with immuneescape mutations after ocrelizumab treatment for multiple sclerosis. Open Forum Infect Dis. 2019;6(1):ofy356.

196. Nicolini LA, Canepa P, Caligiuri P, Mikulska M, Novi G, Viscoli $\mathrm{C}$, et al. Fulminant hepatitis associated with echovirus 25 during treatment with ocrelizumab for multiple sclerosis. JAMA Neurol. 2019;76(7):866-7.

197. Hotermans C, Belachew S, Moonen G, Delwaide J. Severe liver dysfunction in a patient with multiple sclerosis: the guilty party is not always the disease-modifying therapy. Multiple sclerosis (Houndmills, Basingstoke, England). 2009;15(11):1378-9.

198. Tamura S, Warabi Y, Matsubara S. Severe liver dysfunction possibly caused by the combination of interferon beta-1b therapy and melilot (sweet clover) supplement. J Clin Pharm Ther. 2012;37(6):724-5.

199. Tremlett H, Fu P, Yoshida E, Hashimoto S. Symptomatic liver injury (hepatotoxicity) associated with administration of complementary and alternative products (Ayurveda-AP-Mag Capsules $(\circledR))$ in a beta-interferon-treated multiple sclerosis patient. Eur J Neurol. 2011;18(7):e78-9.

200. Mack CL, Adams D, Assis DN, Kerkar N, Manns MP, Mayo MJ, et al. Diagnosis and Management of Autoimmune Hepatitis in Adults and Children: 2019 Practice Guidance and Guidelines From the American Association for the Study of Liver Diseases. Hepatology. 2020;72(2):671-722.

201. de Seze J, Canva-Delcambre V, Fajardy I, Delalande S, Stojkovic $\mathrm{T}$, Godet E, et al. Autoimmune hepatitis and multiple sclerosis: a coincidental association? Multiple Sclerosis (Houndmills, Basingstoke, England). 2005;11(6):691-3.

202. Cação G, Santos E, Martins SA. Concurrent autoimmune hepatitis in multiple sclerosis. Multiple Sclerosis (Houndmills, Basingstoke, England). 2018;24(3):350-3.

203. Wolinsky JS, Narayana PA, O'Connor P, Coyle PK, Ford C, Johnson K, et al. Glatiramer acetate in primary progressive multiple sclerosis: results of a multinational, multicenter, doubleblind, placebo-controlled trial. Ann Neurol. 2007;61(1):14-24. 